\title{
PIEDRAS BLANCAS MOTEL FEASIBILITY STUDY AND REDEVELOPMENT ALTERNATIVES
}

\author{
A Professional Project \\ presented to \\ the Faculty of California Polytechnic State University, \\ San Luis Obispo
}

\author{
In Partial Fulfillment \\ of the Requirements for the Degree \\ Master of City and Regional Planning
}

by

Gordon Douglas Anderson

June 2010 
(C) 2010

Gordon Douglas Anderson

ALL RIGHTS RESERVED 


\section{COMMITTEE MEMBERSHIP}

TITLE:

Piedras Blancas Motel Feasibility Study and Redevelopment Alternatives

AUTHOR:

Gordon Douglas Anderson

DATE SUBMITTED:

June 2010

COMMITTEE CHAIR:

Hemalata Dandekar, PhD., (Department Head, City and Regional Planning)

COMMITEE MEMBER: $\quad$ Emmit Bud Evans, PhD., (Faculty Emeritus, Political Science)

COMMITTEE MEMBER: $\quad$ Lisa Wise, (President, Lisa Wise Consulting, Inc.) (Guest Lecturer, City and Regional Planning) 


\section{ABSTRACT \\ Piedras Blancas Motel Feasibility Study and Redevelopment Alternatives \\ Gordon Douglas Anderson}

The Piedras Blancas Motel is a 1950's era roadside motel comprised of 11 lodging units, plus a cafe, laundry room, manager's apartment, and adjacent storage area. It is located seven miles north of San Simeon and nine miles south of the San Luis Obispo/Monterey County line. In 2005, the property was purchased using State, Federal, and private funds, and then transferred to the California Department of Parks and Recreation (State Parks). Although it has been closed to the public since 2005, the Site offers day-use parking and convenient beach access.

This professional project, under contract with the California Coastal Conservancy, provides information necessary for the future redevelopment of the Piedras Blancas Motel. It demonstrates the feasibility of a preferred development alternative through several analyses including: a structural analysis of the existing building(s), a constraints analysis, an evaluation of regulatory requirements, and an assessment of redevelopment options based on preliminary market research and financial analysis.

The primary objective of the Coastal Conservancy and State Parks is to provide low-cost overnight lodging and visitor services along the Big Sur Coast. The Motel would serve as an alternative to existing expensive lodges or resorts as well as existing tent or RV camping that may not serve as an option for some visitors.

Keywords: Redevelopment, Coastal Redevelopment, Lodging, Coastal Zone, Market Analysis. 


\section{ACKNOWLEDGMENTS}

I would like to thank Henry Pontarelli and Lisa Wise for suggesting that I use the Piedras Blancas Motel as my Professional Project, and for their guidance, assistance, and mentorship. I would also like to acknowledge and kindly thank the members of my academic committee, Hemalata Dandekar and Bud Evans. Their insights and perspective were invaluable to this project. 


\section{PREAMBLE}

In the spring of 2005, I graduated from the University of Miami, Florida and decided to move to Los Angeles. The route to my new home stretched across the country and then turned south down the long California coast. When I reached the section of Highway 1 between Carmel and San Simeon, known as the Big Sur Coast, the beauty of the land and how it appeared to remain relatively untouched amazed me. I developed an immediate affinity for the area, and decided that I should make an effort to return as often as possible. But I was unaware at the time how much this area would become a part of my life.

At the same time that I was planning my trip to California, the Trust for Public Lands (TPL) was finalizing a deal to purchase a little motel north of San Simeon called the Piedras Blancas Motel. The purchase was partially financed by a large contribution from the California Coastal Conservancy (Coastal Conservancy). Until 2005, the Motel had been privately operated and served as a low-cost option to travelers driving to and from Big Sur or visiting the Hearst Castle. But now the Motel had fallen into disrepair. TPL closed the Motel to the public and transferred ownership to the California Department of Parks and Recreation (State Parks) to be incorporated into the larger Hearst San Simeon State Park.

During the summer before my second year of graduate school, I began an internship at Lisa Wise Consulting, Inc. (LWC) in San Luis Obispo. The previous year, LWC had won a contract from the Coastal Conservancy to perform a feasibility study for the Piedras Blancas Motel. However, due to State budget cuts and a work stoppage, very little work had been completed. The project happened to come back online at the same time that I was beginning to gather ideas for a professional project for my Master's Degree. My supervisor at LWC, Henry Pontarelli, informed me that the State work stoppage had ended and that the Piedras Blancas Motel project would resume shortly. He offered to allow me to continue working at LWC on this project, while simultaneously using it to fulfill the academic professional project requirement. I enthusiastically agreed and began working immediately.

To set the groundwork for the project, I felt that I must first understand the history of the Piedras Blancas Motel and the surrounding area, including the Big Sur Coast and San Simeon. I read historical account, memoirs, archival planning documents, and guidebooks in order to discover significant historical episodes that were not immediately evident. What I learned is that the Big Sur Coast, San Simeon, and the Piedras Blancas Motel each have a deep and colorful history involving multiple publics and diverse individuals. It is the idea of the multiple publics that I have tried to keep at the forefront throughout the entirety of this project.

Once I understood the history and culture of the area, and learned about the multiple publics who visit throughout the year, I began a market study to find out if there were overnight lodging accommodations to serve everyone. What would be the best way to accommodate the overnight lodging needs of a diverse public, within a market that seemed to favor either high-end luxury or low-end camping? Was it feasible to operate a low-cost lodging facility that was not tent or RV camping? These were some of the questions that needed to be answered by a market analysis. 
To do the market analysis, I first defined the market area, establishing parameters based on proximity, use, and user profile. To be included in the market area, a facility needed to be on, or very near, the Big Sur Coast. It also had to incorporate overnight lodging uses such as hotel, $\mathrm{RV} /$ tent camping, or tent cabins/yurts. Another, more subjective parameter, was that a facility in the market area must appeal to the sensibilities of a visitor interested in truly enjoying the natural beauty of the Big Sur Coast. For example, hotels in Morro Bay were not included in the market analysis, even though Morro Bay is less than 40 miles from the Piedras Blancas Motel. Similarly, Monterey was not included in the study, even though it is approximately 30 miles form Big Sur. I chose to acknowledge in the market analysis that the Big Sur Coast is inherently different, and appeals to a different type of traveler, than tourism oriented beach towns such as Morro Bay and Monterey.

A complete inventory of all lodging facilities within the market area was conducted. The inventory contained information about the facility's location, cost, and accommodation types (i.e., hotel, tent, RV, or tent cabin/yurt). I discovered that between San Simeon and Big Sur, there were almost no low cost lodging accommodations available that were not tent or RV camping. In other words, if a family decided to spend a weekend along the Big Sur Coast, their only options would be to camp in a tent or RV, or to spend several hundred dollars at a lodge or resort.

Although an understanding of the market deficiencies is important, it could only be put to practical use if coupled with a thorough analysis of the Site's regulatory environment. I had several ideas of ways to redevelop and operate the Site that would be unique, fun, affordable, and aesthetically pleasing. I envisioned site design that would incorporate at least a portion of the existing building with new development of beach cottages and tent cabins. It could include common areas with fire pits, dining areas, and trails to the beach. An educational facility could be built to inform visitors about the Site's history and the unique wildlife and vegetation that are in the vicinity. But the question still remained, what was State Parks allowed to do at the Site? What form would the redevelopment take?

I read and examined all of the relevant planning documents and permitting procedures in order to ensure that the preferred development alternative would be compatible with the regulations established by the County and the California Coastal Commission. Building heights are restricted to 15 feet. Building footprints must occupy no more than 40 percent of the parcel. Views of the ocean must be protected and maintained. Buildings cannot be within 50 feet of the coastal bluff. The list of regulations is extensive. Therefore, the final development alternative had to be tailored to the specifications of the existing regulations.

For example, RV camping had been a historic use at the Site. However, recreational vehicle parks are not an allowed use under the North Coast Plan. Therefore, State Parks will not be allowed to reinstate RV camping as a use. Another idea considered was to utilize the land that will be added to the parcel after the realignment of Highway 1 . However, this land is under a conservation easement that prohibits many commercial uses including, overnight lodging, restaurants, and retail.

The final tasks outlined in the project's scope of work are the illustration of the preferred development alternative and a financial analysis of the alternative. The preferred development 
alternative incorporated existing regulations into a plan that was capable of meeting salient market deficiencies. Joel Snyder, from Caron Design, created three architectural illustrations representing three distinct levels of development at the Site. These illustrations were presented to the County of San Luis Obispo Planning Department at a pre-application meeting held on April 26. We used feedback from the County to narrow our options and finalize the illustration for our preferred alternative. Then each aspect of the plan was assigned a cost in order to determine its financial feasibility. A basic pro-forma spreadsheet calculated the financial performance of the Motel over a 30 year time period.

Although the architectural illustrations and the financial analysis were preformed as part of the project for the client, they are not included in this submission of the academic professional project because they were considered proprietary information at the time of submission.

As project manager, I devoted over 350 hours to writing, researching, creating maps and graphics, and facilitating project logistics. Because I was acting as a representative of LWC, Henry and Lisa had to trust me and depend on my professionalism, organization, and the quality of work. I scheduled and participated in three Site visits, two meetings with the San Luis Obispo County Planning Department, and three academic committee meetings. These meetings are in addition to weekly staff meetings where I reported on the status of the project, and regular team meetings with Mr. Pontarelli, Ms. Wise, a local architect, and the client representative from the Coastal Conservancy. I managed a scope of work, timeline, and budget, adjusting or amending each as necessary. Additionally, I coordinated with various subcontractors, including an architect and structural engineer. All of these tasks were crucial to the comprehensive professional and academic learning experience.

The most rewarding part of the project is to know that I played an integral role in ensuring that the Piedras Blancas Motel site will be enjoyed by generations to come. It is not that hard to imagine that under different circumstances, the Motel could have been bought by another entity that was not as concerned with providing low-cost lodging accommodations, accessible to multiple publics. It could have been redeveloped into another high-end lodge or a hotel only to be enjoyed by the wealthy. Or it could have simply faded away, neglected at first and then eventually abandoned. But thanks to the California Coastal Conservancy, Trust for Public Lands, State Parks, and others, a new phase in the history of the Site has begun. 
Piedras Blancas Motel

\section{FEASIBILITY STUdY \\ and Redevelopment Alternatives}
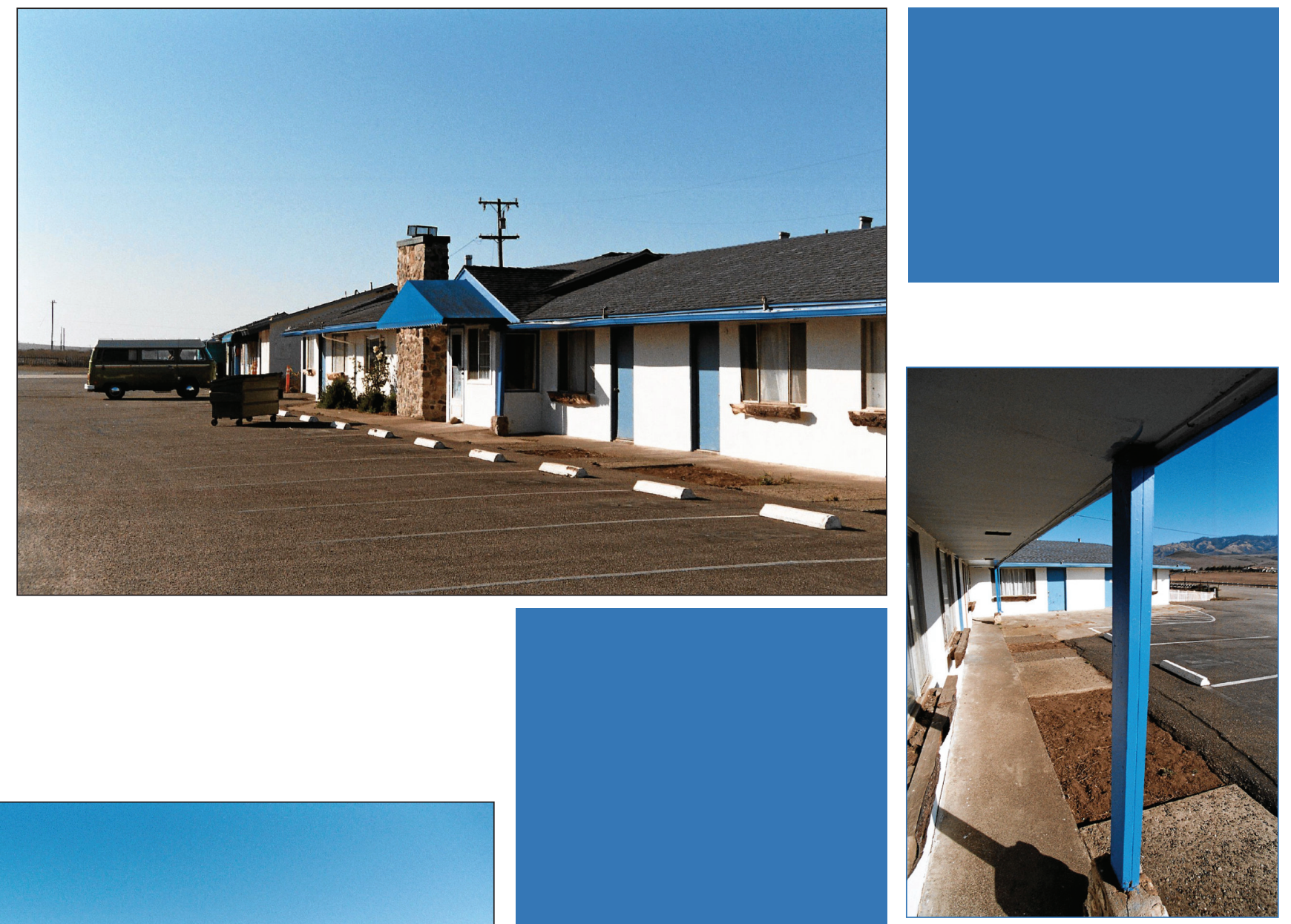

Background Report

Academic Draft

June, 2010

(C)

Coastal

Conservancy

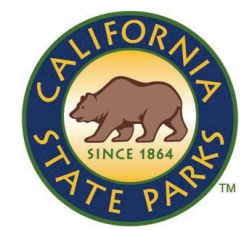

lisa wise consulting, inc.

planning economics

natural resources 



\section{Piedras Blancas Motel}

FEASIBILITY STUDY

and Redevelopment Alternatives

Background Report

Administrative Draft, May, 2010

Funded by the California Coastal Conservancy

\section{Consultant Team}

Lisa Wise Consulting, Inc.

Caron Design Group

Taylor and Syfan

\section{California Coastal Conservancy}

Tim Duff

\section{California Department of Parks and Recreation}

Nick Franco

Juvetino Ortiz

Doug Barker

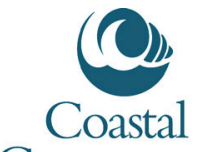

Conservancy

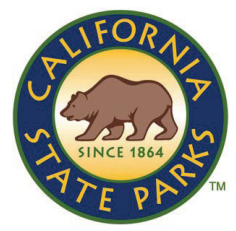

\section{lisa wise consulting, inc.}

planning 
Background Report

This Page Intentionally Left Blank 


\section{Table of Contents}

Introduction

Chapter 1: Social and Cultural Analysis..... 1

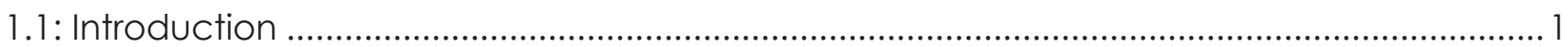

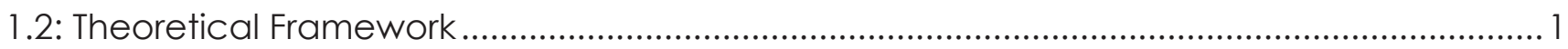

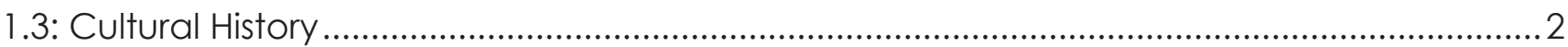

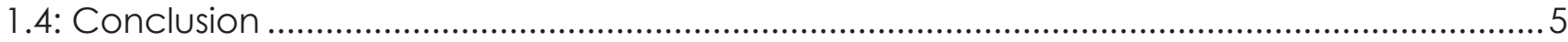

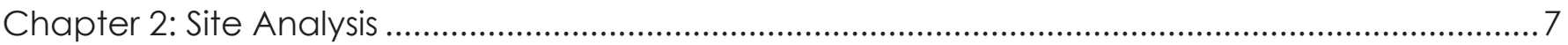

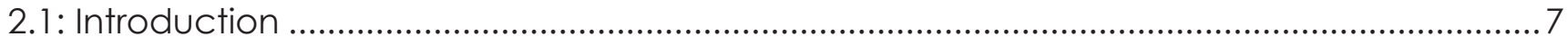

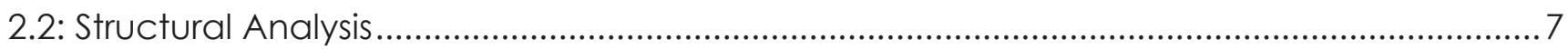

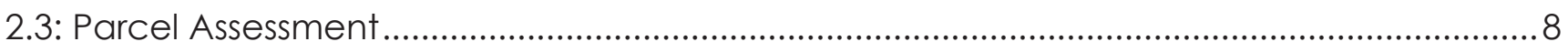

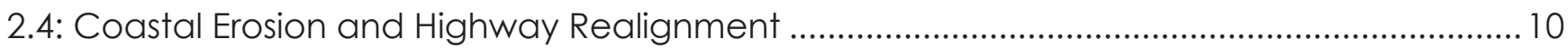

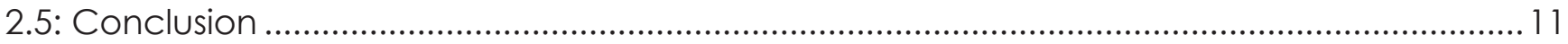

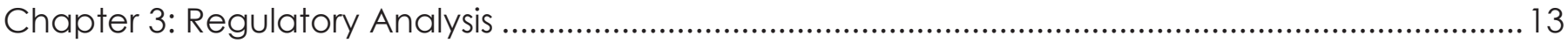

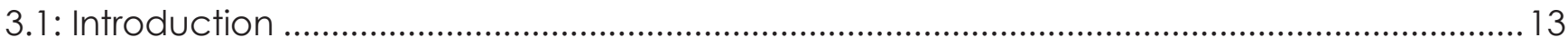

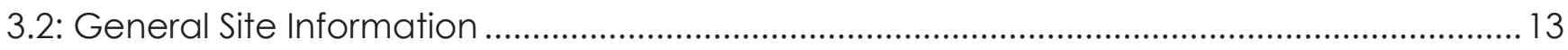

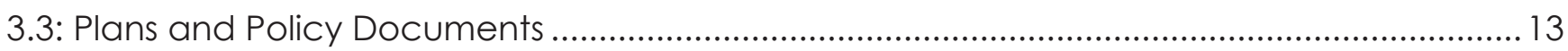

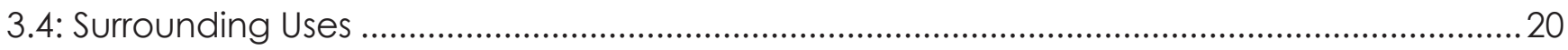

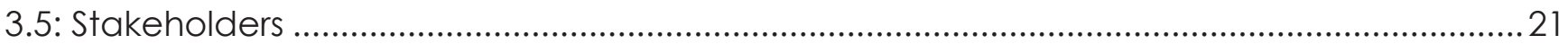

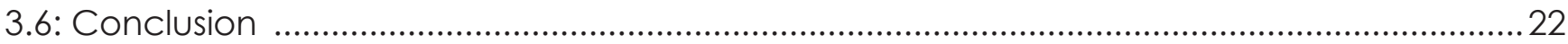

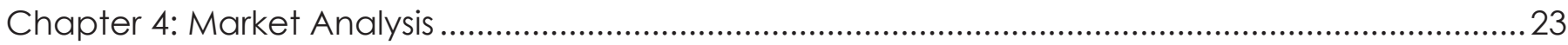

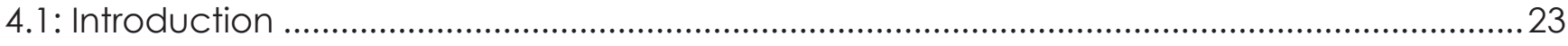

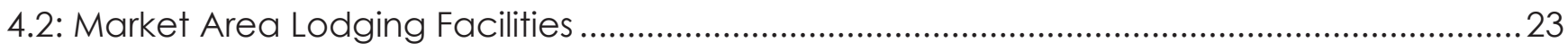

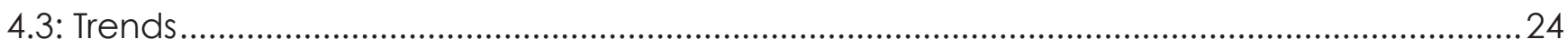

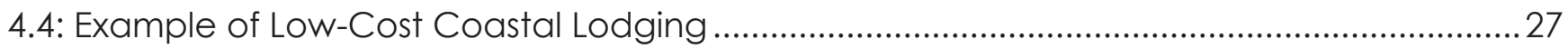




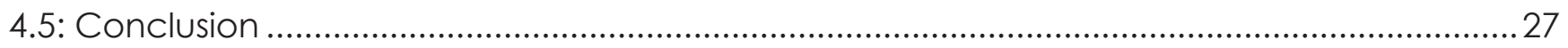

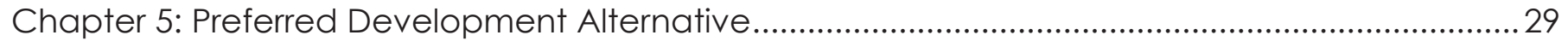

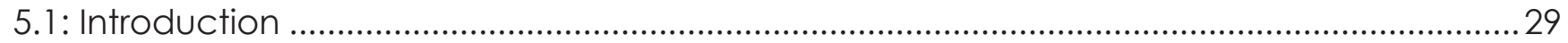

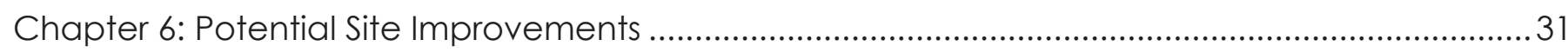

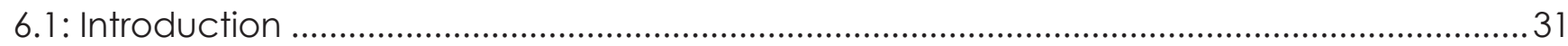

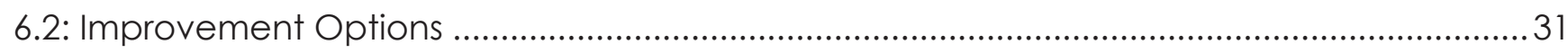

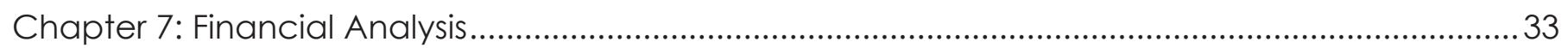

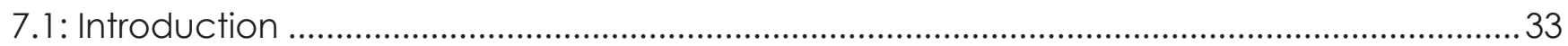

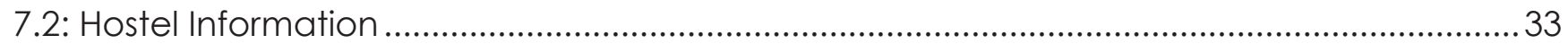

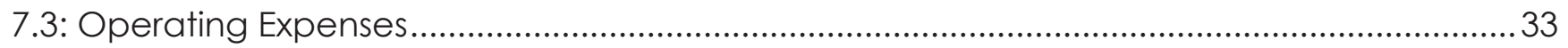

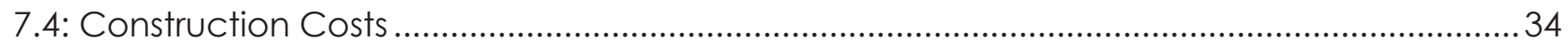

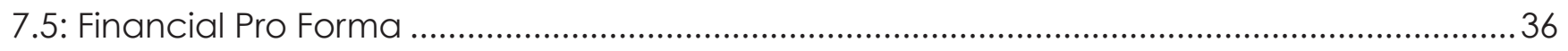

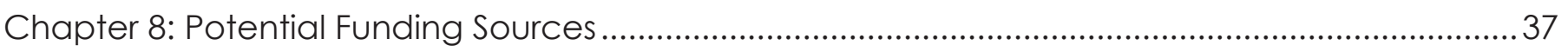

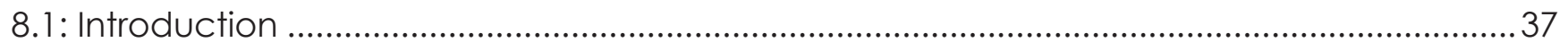

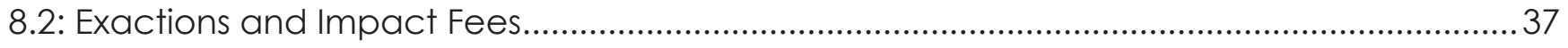

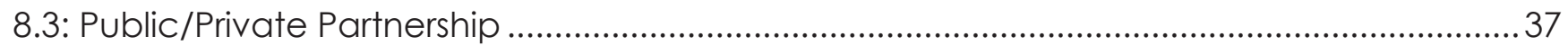

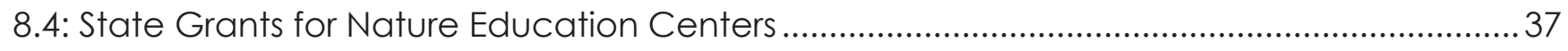

8.4: California Coastal Conservancy, California Coastal Trail.........................................................38

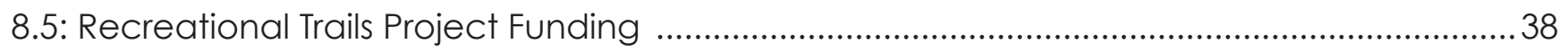

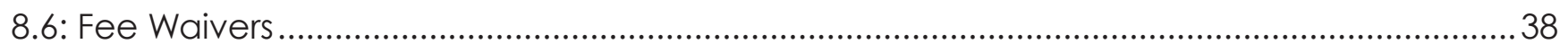

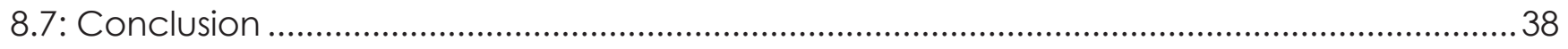

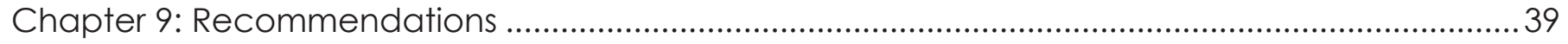

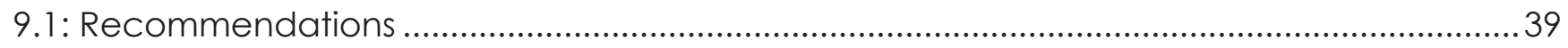

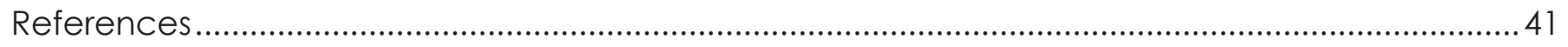




\section{List of Figures}

Figure i Map of Hearst San Simeon State Park............................................................................ii

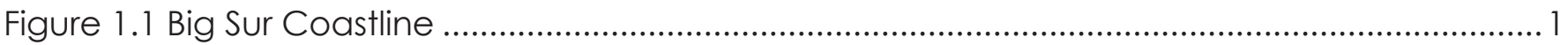

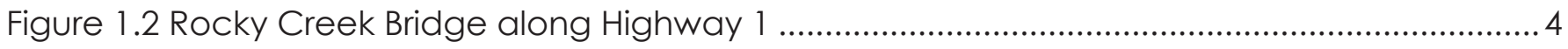

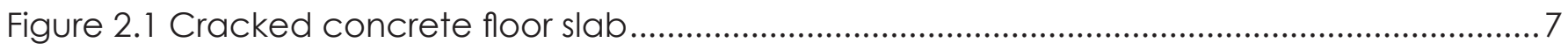

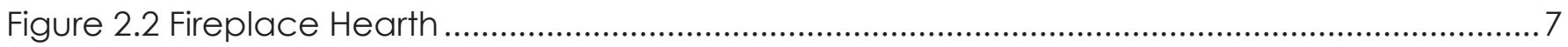

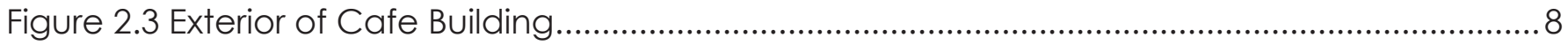

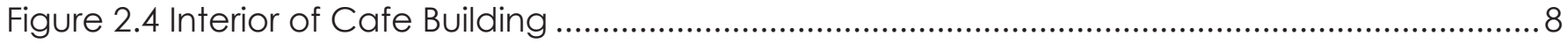

Figure 2.5 Ice plant on west side of Motel .....................................................................................

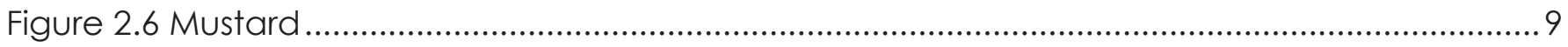

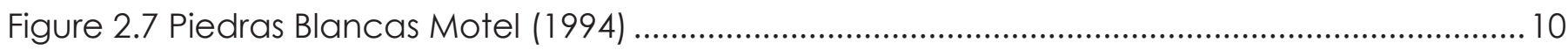

Figure 2.9 Proposed realignment (yellow) and 15 year erosion (red) ….......................................... 10

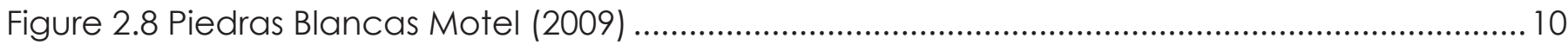

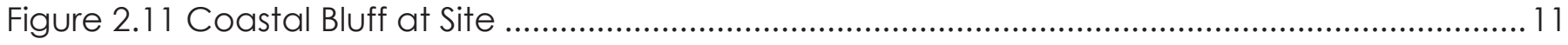

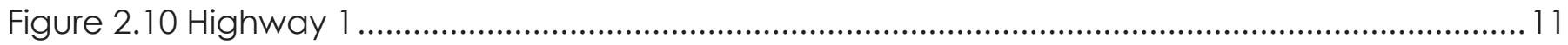

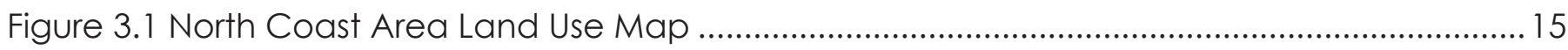

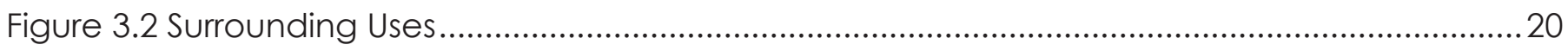

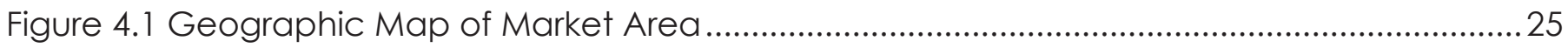

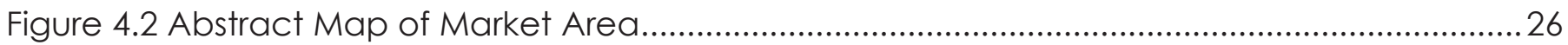


Background Report

This Page Intentionally Left Blank 


\section{Introduction}

In May 2005, the Trust for Public Land, with $\$ 4.5$ million in grant funding from the California State Coastal Conservancy (Coastal Conservancy) and Federal and private funds, purchased the Piedras Blancas Motel property (Site). The property is comprised of 25 acres of coastal bluffs, two beaches, and a half-mile of shoreline located midway within the 18-mile long Hearst San Simeon State Park. The Site is seven miles north of San Simeon, nine miles south of the San Luis Obispo/Monterey County line and one mile north of the Piedras Blancas Lighthouse. The motel complex is comprised of 11 lodging units, plus a cafe, laundry room, manager's apartment, and adjacent storage area.

Later in 2005, the property was transferred to the California Department of Parks and Recreation (State Parks) and has been open to the public since. Although the motel has been closed to the public since 2005, the Site offers day-use parking and convenient beach access.

To assist State Parks in developing a feasibility study for the future reuse of the Site, the Coastal Conservancy funded the preparation of this report which includes a structural analysis of the existing building(s), a constraints analysis, evaluation of regulatory requirements, and an assessment of redevelopment options based on preliminary market research, and financial analysis.

The area in the vicinity of the Piedras Blancas Motel is commonly considered the southern gateway to the world famous Big Sur coastline, a spectacular, cliff-hugging 90 miles of coast that was designated the State's first National Scenic Byway in 1965. Near-by attractions include the Hearst Castle, an elephant seal haul out and rookery, and the Esalen Institute.

Significantly, the property is located in the middle of Hearst San Simeon State Park, which extends for 18 miles from San Carpafaro Creek to the north, to Moonstone Beach to the south. Established in 2004, when State Parks acquired roughly 1,000 acres west of Highway 1, from the Hearst Corporation, this Park creates exciting opportunities to develop new segments of the California Coastal Trail, including links to the Site. In addition, as a result of conservation agreement between the State and the Hearst Corporation, much of the land to the east of Highway 1 is protected by conservation easements. Consequently, the beaches, blufftops and open space lands surrounding the Site will remain largely undisturbed, while also providing the State Department of Transportation (Caltrans) with land needed to realign Highway 1 inland. The realignment will be discussed in more detail in section 2.4 . 


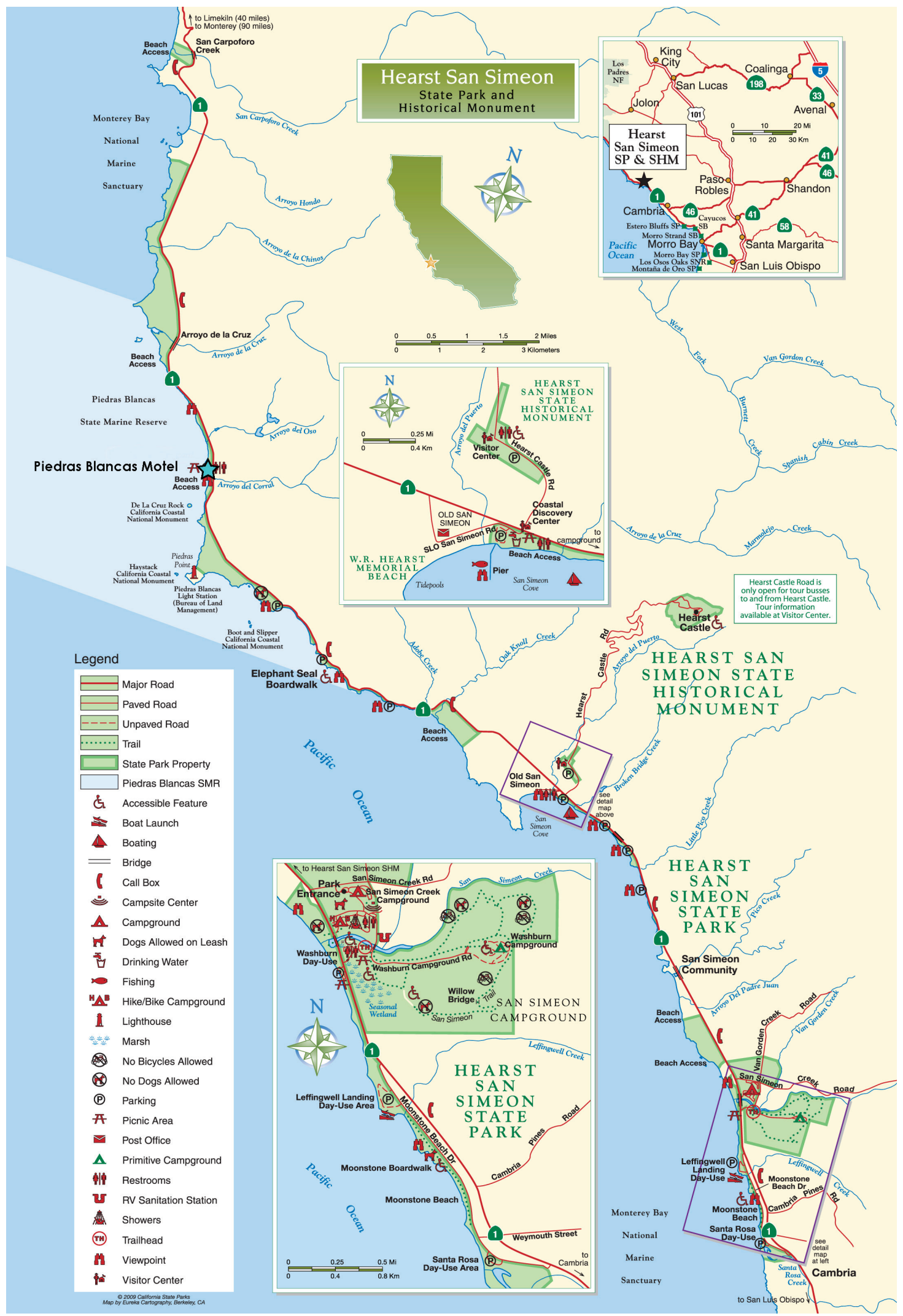

Figure i Map of Hearst San Simeon State Park 


\section{Chapter 1: Social and Cultural Analysis}

"This is the California that men dreamed of years ago, this is the Pacific that Balboa looked out on from the Peak of Darien, this is the face of the earth as the Creator intended it to look."

- Henry Miller on Big Sur, 1957

\section{1: Introduction}

The Big Sur coastline is sacred to many people regardless of race, education level, income, or place of birth. Much of this sentiment is due to the fact that, even today, it remains mostly undeveloped and lacking many of the encumbrances and distractions of modern society (e.g., billboards, fast-food restaurants, etc.). Driving along Highway 1 between San Simeon and Carmel requires a certain amount of patience. The winding cliffhugging road demands slow speeds and vigilance. One needs a sense that it is not the destination but the journey that is important.

Big Sur's rugged terrain made it nearly inaccessible by land until the 1930s. Prior to this time, those lucky enough to gaze upon its rocky shore and roam the coastal bluffs spoke of the area as though it were a closely guarded secret. This mystique has resulted in a cultural history that is unique in America, appealing to individualists, artists, outcasts, eccentrics, naturalists, spiritualists and sojourners, as well as vacationing corporate types and middle-class travelers from the U.S. and around the world. Labels such as "paradise" or "utopia" have oftentimes been attributed

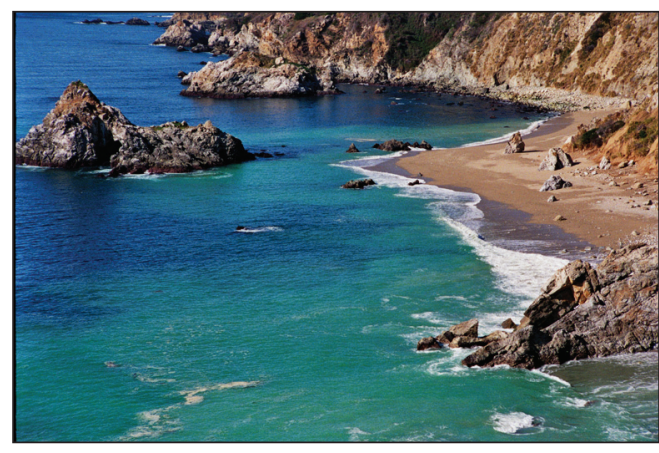

Figure 1.1 Big Sur Coastline to this land, but the reality is much more complex. Indeed its multifaceted nature can even be harsh and contradictory at times. The Big Sur coast certainly possesses a unique social and cultural environment that requires special considerations.

This chapter provides a summary of the social and cultural history of the Big Sur coast as it relates to the Piedras Blancas Motel, including the adjacent areas of San Simeon and the Big Sur coastline. The historical component of the chapter is not intended to be exhaustive, but rather to introduce the reader to possibly forgotten histories. It is also intended to give the reader a sense of how the Piedras Blancas Motel came into being and why its location is unique. But first, this chapter establishes a theoretical framework through which one can critically analyze proposals for redevelopment within this unique locale.

\section{2: Theoretical Framework}

When considering a redevelopment project along the Big Sur coast, an essential first step is to take into account the social and cultural history of the area. Drawing on historical accounts, memories, and tacit knowledge 
from local residents and historians can assist in guiding the appropriate course for development. As Dolores Hayden wrote in her 1995 book, The Power of Place, "Cultural landscape history can strengthen the links between previously disparate areas of practice that draw on public memory. And conscious effort to draw out public memory suggests new processes for developing projects."

Hayden's ideas can be drawn upon to guide the redevelopment of the Piedras Blancas Motel. It is a place that over time has catered to people of diverse backgrounds but who share the common experience of the Big Sur coast. Hayden explains:

Place memory encapsulates the human ability to connect with both the built and natural environments that are entwined in the cultural landscape. It is the key to the power of historic places to help citizens define their public pasts: places trigger memories for insiders, who have shared a common past, and at the same time places often can represent shared pasts to outsiders who might be interested in knowing about them in the present.

She contends that when people occupy an area, they become connected to the landscape and are influenced by it. In the same way that humans can re-shape and develop land, the land itself is capable of affecting those that occupy it. Understanding this relationship between land and people provides the developer with valuable insights, and possibly the foresight to create suitable project strategies

\section{3: Cultural History}

The following paragraphs summarize brief periods in the history of the San Simeon/Big Sur area that have been influential in, and provide context for, how the Piedras Blancas Motel came into being.

\section{Native Inhabitants}

The coastal lands surrounding present-day San Simeon were once occupied by the Playa Salinan Indians (Playas), one of three divisions of the Salinan Indian tribe of Central California. The Playas had no formal government or even a name to refer to themselves. They lived in small groups, residing near the coast in the winter and spring months, then moved slightly inland during the late summer and fall to harvest nuts, berries and other edible plants. Although they lived near the sea, they seldom fished. The Playas' diet consisted mostly of nuts, roots, berries, grass seed and the occasional small rodent or waterfowl (Hamilton, 1974)

\section{Spanish Settlement}

In 1542, Juan Rodriguez Cabrillo was the first European to explore the Big Sur coastline. From his ship, he sighted and named Piedras Blancas (white rocks) Point for the large white rocks that protrude from the sea at this point. But it was not until the expedition of Gaspar de Portola in 1769 that Spaniards began to colonize this area. It was the Spanish who gave the Playa Salinan Indians their name during the establishment of the area missions (San Antonio in 1771, San Luis Obispo in 1772, and San Miguel in 1779). At this point many of the natives were converted to Christianity, enslaved by the Spaniards, or exposed to deadly new diseases that nearly destroyed the tribe altogether. In fact, there were no Playas living outside of Mission compounds after 1800 (Hamilton, 1974). 


\section{Mexican Land Grants}

After the Spanish were overthrown by the people of Mexico in 1821, California fell under Mexican rule. The Missions were left powerless in a secularized land, and quickly lost their influence in California. In 1840, the Mexican government awarded Don Jose de Jesus Pico 48,805 acres of land known as Rancho de la Piedra Blanca. Pico used the land to graze long-horned Spanish cattle, but only visited the ranch house periodically throughout the year (Hamilton, 1974). However, by the mid-1840s, California was in the midst of another conflict, this time between the Mexicans and the Americans.

\section{Early American Settlers}

In 1848, America won the war with Mexico and as a result of the treaty, the U.S. acquired California. American settlers from the east came to California in droves during the gold rush of 1849, and in 1850 California became the 31st State in the Union. These events had significant impacts on Central California as well as the Big Sur coast. Don Jose de Jesus Pico began selling off his land holdings in 1854, and in 1865 a businessman from San Francisco named George Hearst began the incremental acquisition of land surrounding the present day town of San Simeon, including Piedras Blancas Point (Hamilton, 1974). The land owned by Mr. Hearst, and later by his son, newspaper baron William Randolph Hearst, became the 270,000-acre Hearst Ranch $(118,000$ acres located in San Luis Obispo County). The Hearst name became synonymous with the area, and today continues to impact local tourism and development.

\section{Formation of San Simeon}

Settlers continued to arrive in the area from the 1860s throughout the 1870s seeking employment or a parcel of land to farm. While the Hearst Ranch did employ many settlers as ranch hands, a burgeoning lumber industry and the discovery of large cinnabar deposits (ore used for mercury extraction) also provided ample jobs for the new settlers. As population increased and supply ships landed more frequently, George Hearst developed the harbor at San Simeon Bay. By the late 1870s, there was enough commerce, and a large enough population in the area, to support two general stores, two hotels with dining rooms, two saloons, a blacksmith shop, a stable, and a school (Hamilton, 1974).

\section{Piedras Blancas Lighthouse}

During the 1860s and 1870s, ship traffic in and out of San Simeon Bay increased substantially. Captain Joseph Clark established a whaling station at the bay in 1864, with a storage capacity of 600 gallons of whale oil. Sailing ships, and later steam ships, were regularly exporting lumber, produce and cinnabar. Due to the rocky and jagged coastline at Piedras Blancas Point, ships periodically ran ashore, which disrupted the flow of commerce and jeopardized the lives of the crew. It became apparent to many that if growth were to continue in the area, then a lighthouse had to be constructed.

In 1872, the Pacific Lighthouse Board designated Piedras Blancas Point, on land leased by the Army, as the site of the proposed lighthouse. Constructed in 1874, the brick and steel tower reached a height of 110 feet and had a base diameter of 34-feet (Hamilton, 1974). The United States Coast Guard took over control and operation of the lighthouse in 1939. An extensive remodeling took place in 1949, at which time the old lantern was removed and replaced with a 1,000-watt electric bulb (Hamilton, 1974). Although automated and unmanned in later years, the lighthouse is still operational today and provides a significant attraction for 
visitors to the area.

\section{Highway 1}

When Cambria native Elmer S. Rigdon was elected to the California State Senate in 1916, he (and Dr. John L.D. Roberts of Monterey) fought hard to convince the State Legislature to approve the construction of a road that connected Carmel to San Simeon. In 1917, Rigdon introduced a bill, under the Military Roads Act, to create the highway, which was finally passed in two years later. Construction of the road lasted 16 years (1921-

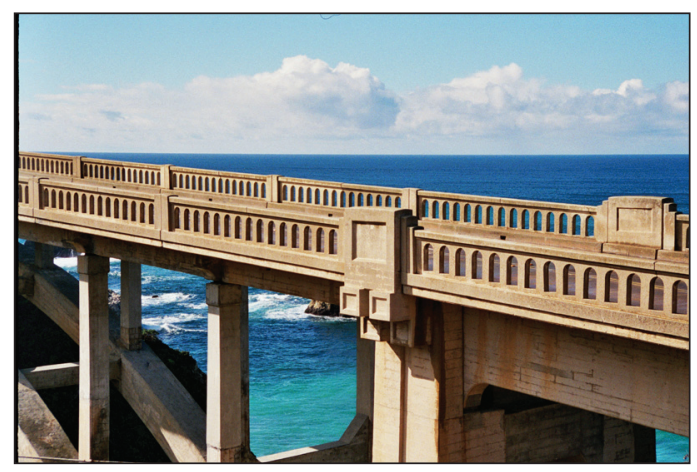

Figure 1.2 Rocky Creek Bridge along Highway 1 1937) and cost nine million dollars (Hamilton, 1974). A work camp was established near the Piedras Blancas Lighthouse, feeding and housing both the engineers and convict laborers (Caltrans, 1996). The Carmel-to-San Simeon Highway did more than just provide additional military security for the State; it allowed the public to safely and easily access the legendary Big Sur coastline. In 1965, the segment of Highway 1 known as the Carmel to San Simeon Highway, was declared the first official "Scenic Highway" in California.

\section{Hearst Castle \& Big Sur Tourism}

Hearst's palatial estate was deeded to the State of California in 1957, six years after his death. The following year, it was opened to the public as Hearst San Simeon State Historical Monument. Visitors, intrigued by the life and death of this enigmatic figure, came in droves to see the enormous house now referred to as the "Hearst Castle." During the 1940s and 50s, Big Sur gained a reputation as an artist's enclave. Whether it was the privacy and solitude, or simply the awe inspiring views, artists of every sort sought out the Big Sur coast as either a temporary muse or permanent residence. Famous writers who lived and wrote here include: Henry Miller, Jack Kerouac, Jack London, John Steinbeck, Mary Austin, Robert Louis Stevenson and others. Ansel Adams and Wynn Bullock immortalized on film many of the breathtaking views along the Big Sur coastline and wooded creeks. One of the first published pieces by journalist Hunter S. Thompson was about the artists living in Big Sur (Monterey County Convention \& Visitors Bureau, 2009).

\section{Piedras Blancas Motel}

In 1959, the first construction took place on the Piedras Blancas Motel parcel (Parcel), although a 1956 aerial photo shows a small structure where the current caretaker residence is located. The development was intended to capitalize on emerging tourism associated with the Hearst Castle, and the increased automobile traffic along this segment of Highway 1. This intention is evident by the subsequent building uses. The first building constructed was the original 11 -unit hotel. Three years later the owner expanded the development to include a café, garage, office, and residence. At some point prior to 1984, three gasoline underground storage tanks were installed for the establishment of an on-site filing station (RRM, 2006, Phase I Environmental Site Assessment).

\section{Big Sur Coast Today}

Human population along the Big Sur coast has never exceeded more than a few thousand. According to the 2000 U.S. Census, Big Sur had a population of 996 (Census 2000 Summary File 1 (SF 1) 93920 5-Digit ZCTA). 
The population of San Simeon was only 470 at the time of the 2000 Census (Census 2000 Summary File 1 (SF 1) 93452 5-Digit ZCTA). The largest employment sectors along the San Simeon and Big Sur are arts, entertainment, recreation, accommodations, and food service. Continuing in the creative tradition, today more than 10 percent of Big Sur residents are working artists (bigsurarts.wikispaces.com).

\section{4: Conclusion}

The areas of Piedras Blancas Point, San Simeon, and Big Sur have remained relatively undeveloped. However the land has shaped and affected the lives of both its inhabitants and visitors, from the basic sustenance that the land provided for the Playa Indians to the artistic inspiration of the natural ambiance. The land has given richly to the local economy in the form of mineral ore, lumber, and grass for cattle grazing. Monuments to notable residents such as William Randolph Hearst and Henry Miller attract thousands of visitors to the area each year. And many more visit each year simply to enjoy the scenic views from Highway 1. Some of these histories are more apparent than others. Regardless, understanding the social and cultural aspects of the area will greatly assist in choosing the appropriate direction for future redevelopment of the Motel site. 
Background Report

This Page Intentionally Left Blank 


\section{Chapter 2: Site Analysis}

\section{1: Introduction}

This chapter presents an analysis of the existing structure of the Piedras Blancas Motel (Structure) and the parcel of land on which it is located (Parcel). Civil engineering firm, Taylor \& Syfan Consulting Engineers, performed a non-invasive structural analysis in December 2008. Section 2.2 provides a summary of this report. Section 2.3 provides an assessment of the Parcel, including geography, climate, soil, plants and fauna. Section 2.4 provides a summary of the proposed Caltrans project to realign State Highway 1 at Point Piedras Blancas. This project will alter access to the Site, but not impede it.

Taylor \& Syfan is a San Luis Obispo-based structural engineering design firm that focuses on specialty structural engineering services, particularly the rehabilitation and retrofitting of historic structures, and, research and development of alternative structural systems and materials (Taylor \& Syfan, 2008).

\section{2: Structural Analysis}

The Piedras Blancas Motel consists of one main motel building and a separate café building. The engineers concluded that although the structures are in need of repair, they are generally suitable for reuse and habitation.

\section{Main Motel Building}

The main motel building consists of 11 guest rooms, a manager's apartment, and a laundry room. The building is wood-framed and sits on a concrete slab foundation. The interior walls consist of drywall and plaster, and the exterior covering is stucco and plaster. Taylor \& Syfan deemed that the walls would require little maintenance in order to provide the necessary lateral strength. Necessary maintenance would include repairing cracks that have developed around doors

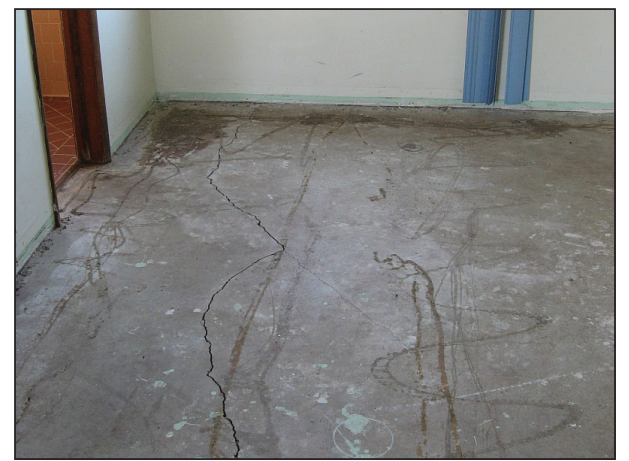

Figure 2.1 Cracked concrete floor slab and windows. Taylor \& Syfan recommend that cracks in the concrete floor slab be addressed. The report also states that the roof appears to be well constructed and "performing adequately." The masonry fireplace located in the manager's apartment will need to be replaced, because it was deemed a seismic hazard. The lower firebox may remain intact, but a new reinforced chimney will be required (Taylor \& Syfan, 2008).

\section{Café Building}

The café building is a single-story wood-framed structure with a concrete slab foundation. It consists of a dining area with a kitchen space, an office area, and an open room that connects the two areas. Adjacent to the café building there

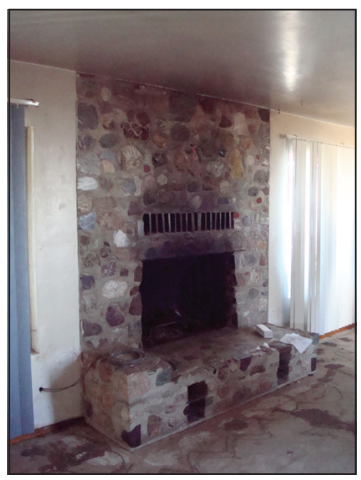

Figure 2.2 Fireplace Hearth 
is a small storage area. Due to the absence of a continuous wall, the café building will require considerably more work than the main building to meet building code requirements. The storage building adjacent to the café was deemed by the engineers to be in severe disrepair and not salvageable. They recommend that the storage area be removed (Taylor \& Syfan, 2008).

The structural assessment concludes that rehabilitation measures be performed as soon as possible to ensure that structural problems do not worsen (Taylor \& Syfan, 2008).

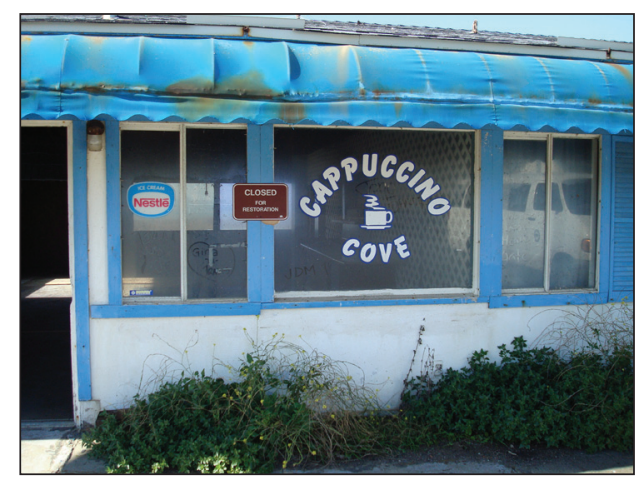

Figure 2.3 Exterior of Cafe Building

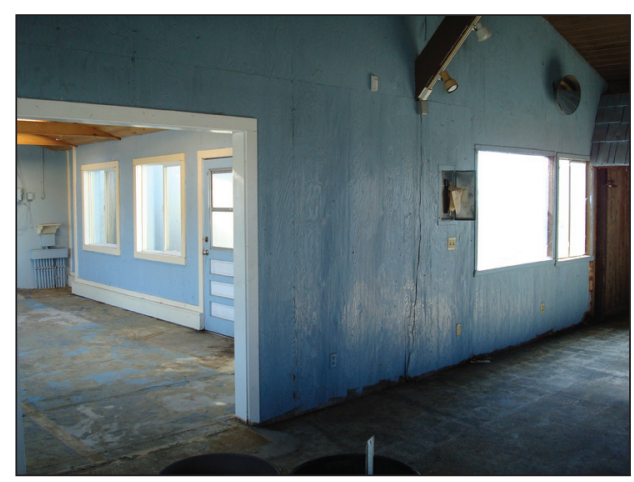

Figure 2.4 Interior of Cafe Building

\section{Geology}

The ground beneath the Piedras Blancas Motel consists primarily of soil made of compressed sand, silt and clay, or loam. RRM's Phase I Environmental Site Assessment classified the surface layer as sandy loam. Below 37 inches, the soil type changes to a fine sandy loam (RRM, 2006).

The Parcel is located within a seismically active region. Several active earthquake faults, including the Simeon, Hosgri and Oceanic (West Huasna) are located within one to four miles from the Parcel.

Soil samples have been tested for traces of hydrocarbons and other contaminants related to the on-site filling station and gasoline underground storage tanks. The tests indicated that there were traces of contaminants in the soil; however, the contamination levels were below regulatory action limits (RRM, 2006).

\section{Climate}

The climate of San Luis Obispo's north coast area is very mild. Temperatures in the summer range from the high 50 s to low 90s. Winter temperatures are cooler and range between the low 40 s to high 60 s. The average rainfall in the area is 22 inches, mainly occurring between November and April. Fog is common along the Central California coastline, especially in the summer months; however, it usually burns off by mid-day.

Wind is another factor to consider at the Site, and can be quite strong at certain times throughout the year. The average wind speed at Point Piedras Blancas is 10.9 miles per hour, with gusts reaching more than 50 miles per hour. During the windiest months of May and June, average wind speeds range between 13 and 14 miles 
per hour (WRCC, 2010).

\section{Plant Communities and Wildlife Habitats}

According to the California Natural Diversity Database (CNDDB), there are a total of 65 special-status plant and wildlife species and plant communities on, and around the site. These include 47 special-status plant species, 14 special-status wildlife species and four sensitive plant communities. The 65 special-status species were identifies as a result of a CNDDB search of the nine 7.5-minute topographical quadrangle maps around and including the proposed project site. Any special-status species or plant community indicated by the CNDDB search was considered as a potential occurrence on the proposed project site. Lists of sensitive plant species, plant communities and wildlife species with potential for occurrence on the Site are included in Tables 1 and 2 .

On February 14, 2010, a site visit was conducted to assess the current flora and fauna conditions of the project site. Note, no focused surveys have yet been conducted, and confirmation of occurrence for these specialstatus species within the general vicinity of the proposed project site would need to be confirmed during such a survey.

\section{Vegetation}

Vegetation on the Parcel is dominated by non-native species, which includes ice plant (Carpobrotus chilensis), kikuya grass (Pennisetum clandestinum), cheese weed (Malva parviflora), perennial mustard (Hirschfeldia incana), and various ornamental species. The Parcel appears to have been disturbed repeatedly over time resulting in numerous non-native and ruderal plant species as was confirmed during the site visit.

\section{Wildlife}

No focused surveys for wildlife species we conducted on the project site for this report. Many of the special-status wildlife species identified in Table 2 as potentially occurring within the vicinity of the project site, would potentially forage within the annual grasslands located on the project site, such as black swift, prairie falcon, the ferruginous hawk, and various bat species. No special-status wildlife species included in Table 2 were observed during the visit to the Site.

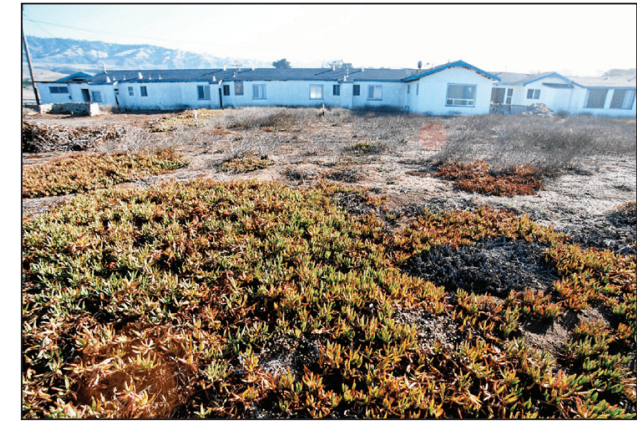

Figure 2.5 Ice plant on west side of Motel

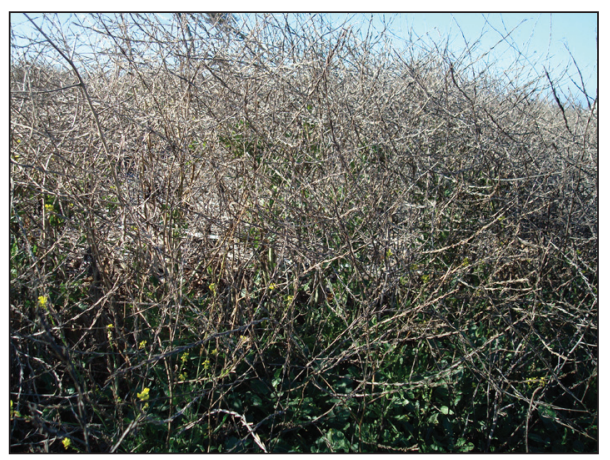

Figure 2.6 Mustard

Approximately 1.5 miles south of the project site is the Piedras Blancas elephant seal rookery, where formal surveys to count seal populations have exceeded counts of 15,000 animals. The rookery is conducive to elephant seal land-based birthing, breeding, molting and resting due to the sandy beaches offering pups protection from high water and a kelp forest that provide protection from predators. The elephant seal rookery is expanding to the north and south with a small group of elephant seals observed along the southern end of the Site.

In addition to the elephant seal rookery, the nearshore and offshore areas provide foraging grounds and 
migration routes for several species of cetaceans (whales, dolphins and porpoises) and seabirds. These include migration routes used by grey and humpback whales, several loon, and sheerwater species, and brandt geese.

Surveys were conducted by State Parks biologists to determine if Smith's blue butterflies (an endagered species) were present on newly acquired land within Hearst San Simeon State Park. Insignificant numbers of host plant were found at the Piedras Blancas Motel Site. The Site is also outside of the known range and has been determined to be unsuitable habitat for the butterflies.

\section{4: Coastal Erosion and Highway Realignment}

Studies have found that the coastline along Highway 1 from approximately the Piedras Blancas Lighthouse

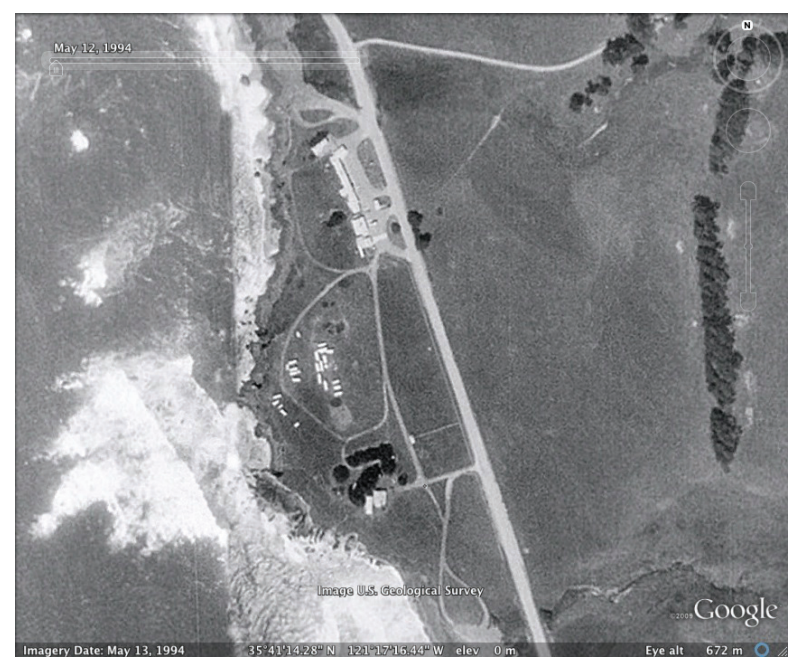

Figure 2.7 Piedras Blancas Motel (1994)

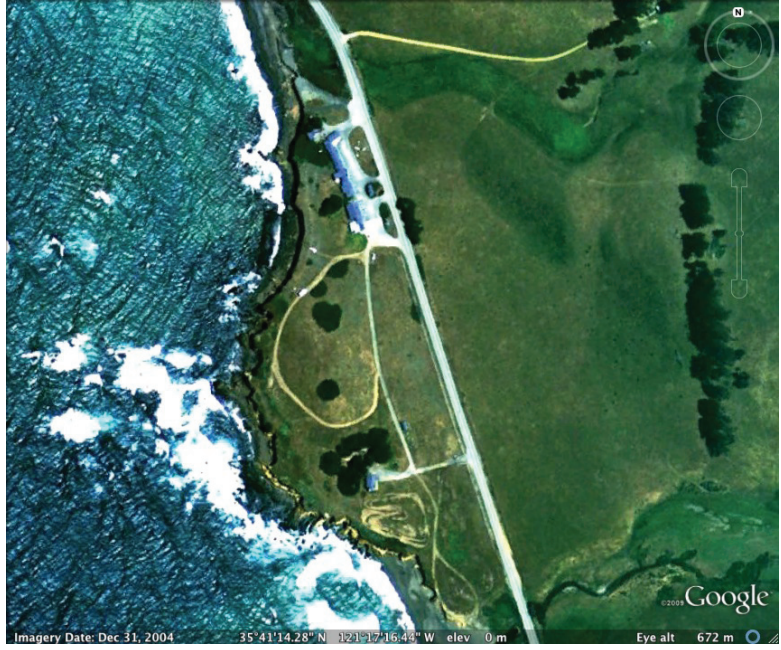

Figure 2.8 Piedras Blancas Motel (2009)

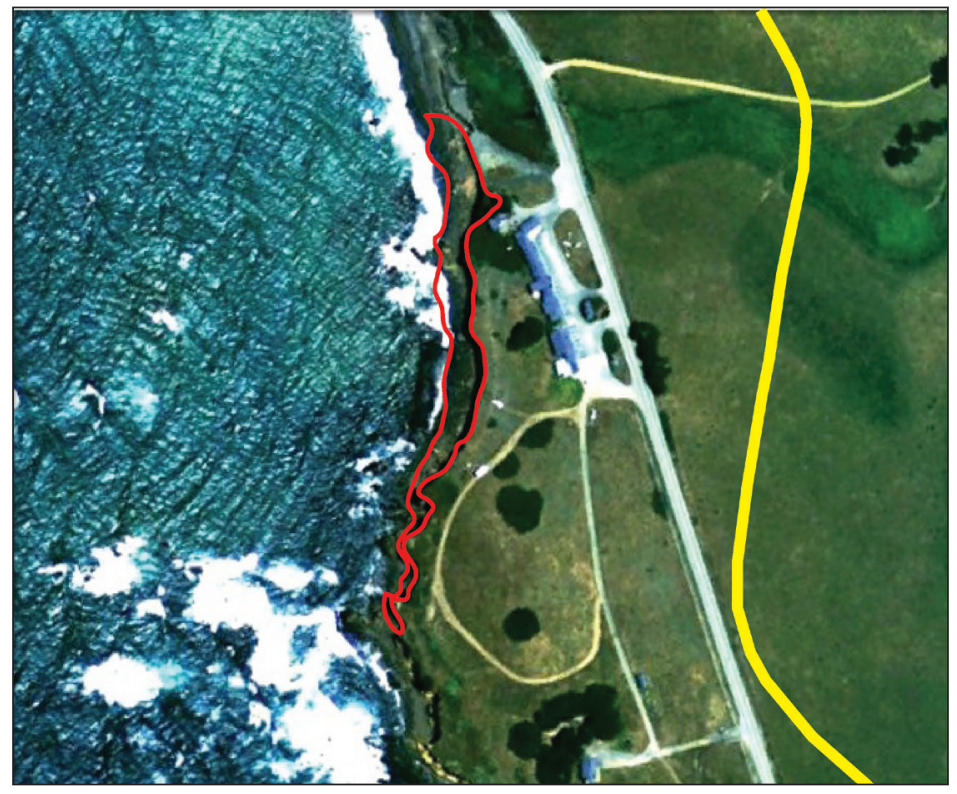

Figure 2.9 Proposed realignment (yellow) and 15 year erosion ( $r e d)$ 
north to the motel site is eroding at a rate of approximately five feet per year (Caltrans, September 2008). Caltrans has attempted to slow the rate in some areas by placing boulders along the shoreline to act as a buffer. This strategy has provided short-term protection of the highway immediately north of the Site, but Caltrans recognizes that a long-term solution is needed.

Due to concerns over coastal erosion, Caltrans has approved the "Piedras Blancas Realignment Project, a plan that will re-route Highway 1 inland up to 475 feet. The Piedras Blancas Realignment Project was approved for funding and Caltrans is in the process of drafting the final EIR, which should be completed by April 2010. The current projected date to begin the bidding process is October 2013. The project is scheduled for completion in 2019. At that time, all land west of the new highway will be transferred to State Parks (Caltrans, 2008, Project Study Report). This will create new opportunities to link the motel site to the California Coastal Trail via the new highway and to the Piedras Blancas Lighthouse.

Funding for the Realignment Project will come from the 2010 State Highway Operation and Protection Program. In August 2008, Caltrans estimated the entire project budget to be $\$ 50.3$ million. This amount includes $\$ 10.9$ million to purchase property within the new 130-foot right-of-way, including the Lighthouse View Estates property north of the Piedras Blancas Motel (Caltrans, 2008). Caltrans is in the process of trying to secure additional project funding.

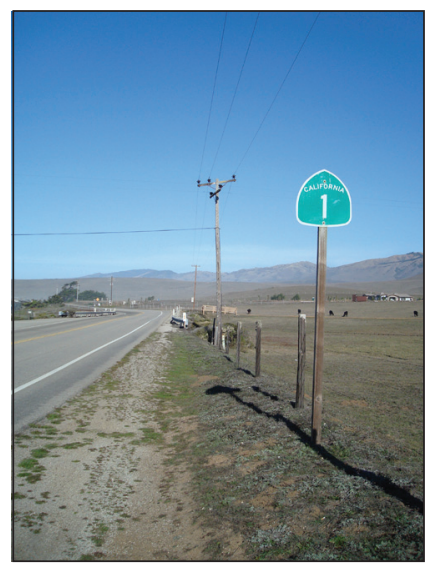

Figure 2.10 Highway 1

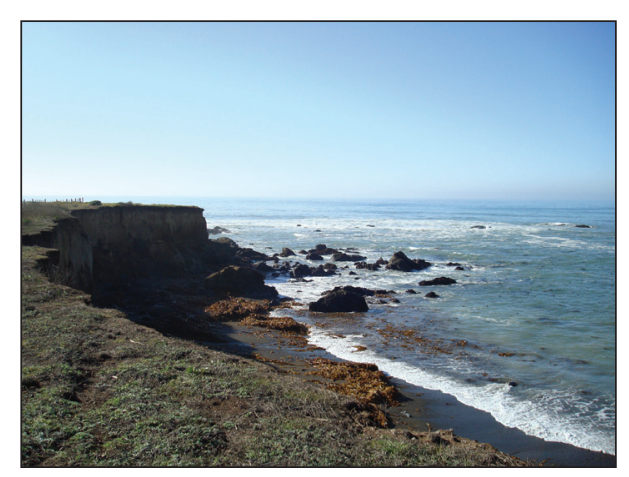

Figure 2.11 Coastal Bluff at Site

See http://www.dot.ca.gov/dist05/projects/slol_piedras/index.htm for complete Caltrans report and Draft EIR.

\section{5: Conclusion}

After a complete parcel assessment, including a structural analysis, Phase I Environmental Assessment, and a biological assessment, several opportunities and constraints have been identified for redevelopment of the Site. The structural analysis indicates that it may be feasible for some of the buildings to be rehabilitated and reused in the existing footprint. Continued coastal erosion will be a major constraint to the redevelopment of the Site, and one that will require a long-term plan and guide the placement of permanent and nonpermanent structures. Another issue related to the coastal erosion is the Caltrans realignment of Highway 1. Caltrans has already made plans to ensure that the site will remain easily accessible. 
Background Report

This Page Intentionally Left Blank 


\section{Chapter 3: Regulatory Analysis}

\section{1: Introduction}

Chapter 3 addresses the enforcement agencies and corresponding planning documents that provide the regulatory oversight applicable to the Site. Due to the Site's location in the Coastal Zone, the applicable regulations are complex, with many of the regulatory documents overlapping or working in conjunction with others. However, the primary planning document for any redevelopment of the Parcel is the San Luis Obispo County North Coast Plan (North Coast Plan). The North Coast Plan provides the most specific information for Site development, and directly refers to the Piedras Blancas Motel. Any information not covered in this document will be addressed in other jurisdictional documents such as the Coastal Zone Land Use Ordinance and the Coastal Plan Policy Document. The following chapter identifies Site jurisdiction and summarizes relevant documents, including the North Coast Plan, Coastal Zone Land Use Ordinance, Coastal Plan Policy Document, Coastal Development Permits, Title 24 and 25, and the Scenic Highway Corridor Protection Plan.

\section{2: General Site Information}

\begin{tabular}{|l|l|}
\hline Year Constructed & 1959 \\
\hline Size & 25 acres \\
\hline Assessor Parcel Number & $011-231-012$ \\
\hline Owner & California Department of Parks and Recreation \\
\hline Jurisdiction & County of San Luis Obispo, Supervisor District 2 \\
\hline Community & Rural North Coast \\
\hline Planning Area & North Coast \\
\hline Land Use Designation & Recreation \\
\hline Combining Designations & $\begin{array}{l}\text { Flood Hazard Area, Sensitive Resource Area, Coastal } \\
\text { Zone Boundary }\end{array}$ \\
\hline Coastal Designation & Wetland \\
\hline Fire Hazard & Moderate \\
\hline Assessed Value & $\$ 4,680,800$ (as of 2009/2010 tax year) \\
\hline
\end{tabular}

\section{3: Plans and Policy Documents}

\section{Jurisdiction}

Under the California Coastal Act, counties and cities are responsible for achieving statewide coastal resource protection goals through the implementation of Local Coastal Programs (LCPS). The Coastal Commission initially worked with San Luis Obispo County (County) officials to ensure that the LCP contained policies and procedures that adequately protect coastal resources and incorporate the objectives of the California Coastal 
Act. When the Coastal Commission certified the LCP in 1988, the County assumed the primary responsibility of issuing coastal development permits.

The Local Coastal Program for the County is the primary planning tool for redevelopment that would take place at the Site. The Local Coastal Program for the County includes:

1. The North Coast Plan (a component of the Local Coastal Plan);

2. Coastal Zone Land Use Ordinance; and,

3. Other implementing actions for the coastal zone that meet the requirements of the California Coastal Act of 1976 as certified by the California Coastal Commission.

\section{North Coast Plan}

The North Coast Plan outlines land uses, development standards, and policies for the coastal zone from Point Estero to the Monterey County line, and inland to the ridge of the Santa Lucia Range. This Plan was updated and certified by the Coastal Commission in 2008, and provides guidance for future land use and redevelopment at the Site. It is the most specific planning document encompassing the Piedras Blancas Motel parcel (Parcel). Anything not covered by the North Coast Plan will be addressed in subsequent County planning documents.

The North Coast Plan designates the Parcel as zoned for recreational uses, although certain commercial uses are also allowed. The site is subject to several development standards as a recreational zone, including those listed specifically for the Piedras Blancas (PB) area (last four bullet points). These standards include (North Coast Plan, 7-1 1, 7-12 and 7-16):

- Development plan approval required for all proposed developments;

- Traffic count projections required for all proposed developments;

- Camping facilities proposals must show location, use, and access point;

- Pedestrian paths are required to link developments to shoreline;

- Setbacks must be a minimum of 50 feet from bluff or high tide line;

- Maximum building height of 15 feet (PB specific);

- Buildings and signs must have natural exterior finishes (PB specific); and,

- Building coverage may be no greater than 40 percent of the site (PB specific).

The land uses listed below are allowed at the Piedras Blancas Motel Site. A principally permitted use is one that is encouraged and has priority over non-principally permitted uses. The Piedras Blancas area is listed in the Plan as a visitor-serving priority area.

Principally permitted uses are limited to:

- Hotels and motels;

- Bed and breakfast facilities; 


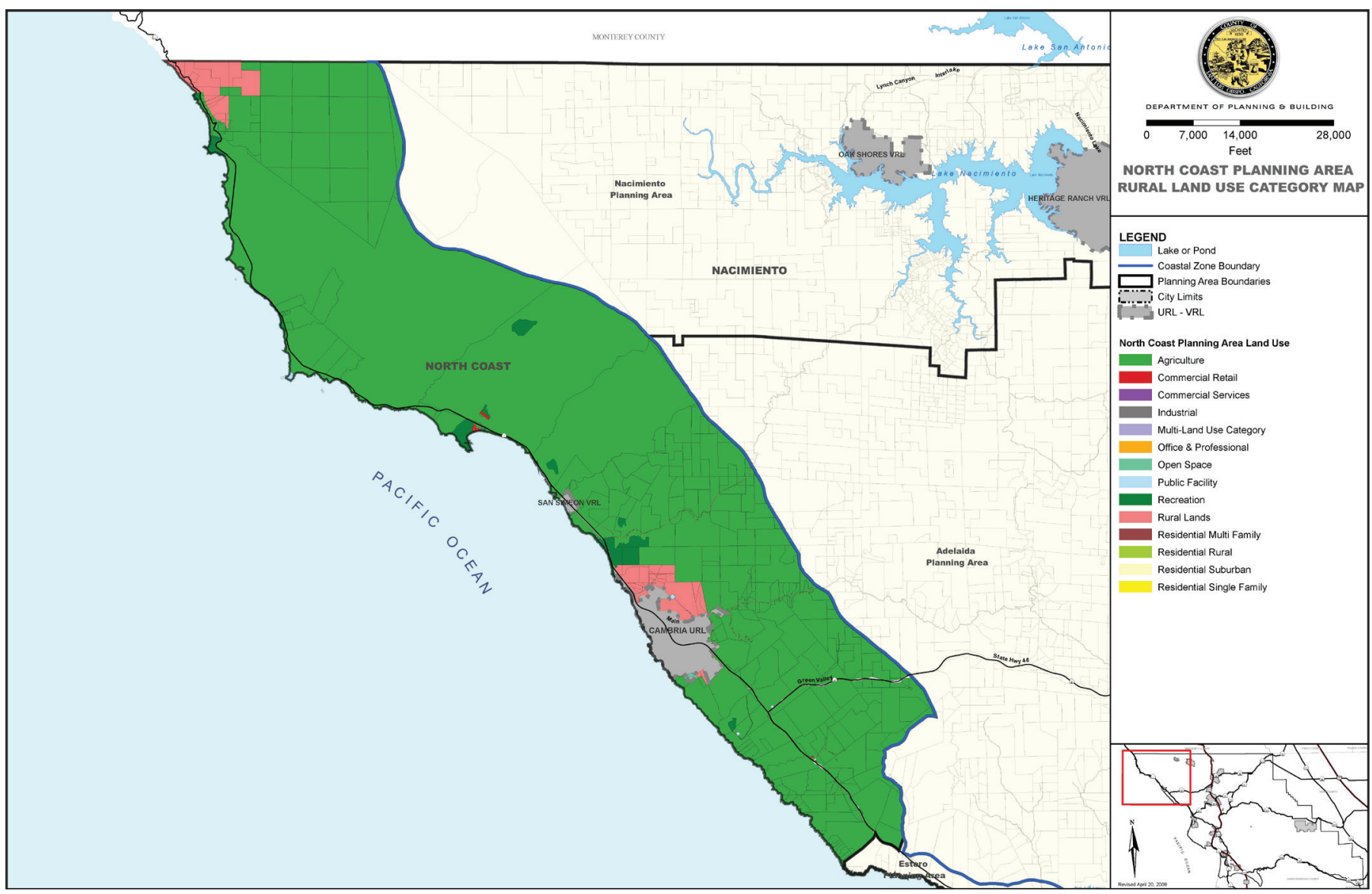

Figure 3.1 North Coast Area Land Use Map

- Eating and drinking places (not including drive-in restaurants, fast food and refreshment stands);

- Food and beverage retail sales (limited to tourist-oriented uses such as gift shops and art galleries); and

- General merchandise stores (limited to tourist-oriented gift shops operated in conjunction with food and lodging facilities).

Non-principal permitted uses are limited to:

- Service stations (limited to one such facility only, existing or rebuilt);

- Caretaker residences:

- Public assembly and entertainment (when accessory to a hotel or motel);

- Coastal accessways;

- Water wells and impoundment; and

- Cultural, education, and recreational uses (excluding libraries, membership organizations, schools, social service organizations, and equestrian exhibition facilities) normally allowed by Coastal Table O pertinent to a visitorserving priority area. 
The Parcel is specifically mentioned in Chapter 7 of the North Coast Plan (2008), stating:

"A small area with a motel, restaurant, and gas station is located along the shoreline 1-1/2 miles north of Piedras Blancas Point. The Recreation land use category could allow for expansion of tourist-recreation facilities. Because of the open exposed shoreline location, however, further development needs to be carefully considered in the development plan review process (North Coast Plan, 2008)."

The North Coast Plan then goes on to suggest that the State of California purchase Piedras Blancas Point (including the motel and the lighthouse), make improvements, and investigate the possibility of developing a hostel or other low-cost lodging facility.

\section{Proposed Hearst Ranch Development}

Two sites in San Simeon are identified in the North Coast Plan as potential location for future visitor serving and commercial development. The two sites are the Hearst Castle staging area and the San Simeon Village area. Staging Area development may consist of a 150-unit motel, specialty retail, restaurants, and galleries. The San Simeon Village area development may consist of the Sebastian's General Store (purchased by Hearst Corporation in December 2009) and the renovation of adjacent historic buildings to offer visitor services and specialty retail. Any development will require a development plan to be submitted to the County. Currently plans for development are in the conceptual planning phase (North Coast Plan, 2008). Although the Hearst Corporation retains the right to pursue these developments, they are still required to obtain the necessary permits. This may also require a General Plan amendment, to ensure compatibility between the proposed development and the North Coast Plan Standards.

The North Coast Plan stipulates in Chapter 7 that, as part of the Hearst Ranch Staging Area development, a campground or youth hostel must be developed within the San Simeon area or at Point Piedras Blancas. According to the North Coast Plan (2008):

"Within four years of the occupancy of the Staging Area phase of the development, the applicant shall construct a youth hostel or campground facility. The facility may be located on either private or public lands, consistent with the standards and policies of the Land Use Element, providing that the site is within one mile of the coast between San Simeon Beach State Park and San Simeon Point (except that Piedras Blancas Point north of San Simeon Point may be used to site such a facility) (North Coast Plan, 2008)."

Hostel requirements:

- Must be Class A;

- Minimum of 100 beds;

- Designed according to American Youth Hostel Association standards;

- Associated costs are the responsibility of the applicant (e.g., design, construction, improvements, etc.);

- Hostel to be operated by non-profit approved by the County (e.g., State Parks); and,

- Applicant may maintain ownership. 
Campground requirements:

- Minimum of 50 campsites;

- Must include both RV and tent camping;

- Constructed according to California Department of Parks and Recreation design specifications; and,

- Applicant may maintain ownership, operation, and control.

\section{Coastal Zone Land Use Ordinance}

The Coastal Zone Land Use Ordinance (CZLUO) (Title 23 of the San Luis Obispo County Code) establishes regulations intended to protect and promote public health, safety and welfare for areas within the County Coastal Zone. The CZLUO applies to all land and development areas within the County's Coastal Zone. Any new development on the Piedras Blancas Motel parcel, including modification, alteration or adaptive reuse of the existing structure, is subject to this ordinance.

The CZLUO applies to the North Coast, Estero and South County planning areas, and is therefore broader in scope than the North Coast Plan. The Land Use Ordinance covers any standards that are not addressed in the North Coast Plan. In the case that a conflict arises between the North Coast Plan and the Coastal Zone Land Use Ordinance, the North Coast Plan standards shall take precedence.

\section{Coastal Bluff Setback}

The CZLUO outlines additional regulations to the minimum 50-foot coastal bluff setback required by the North Coast Plan (CZLUO, 2009). The additional requirements are part of a demonstration of stability report, and are listed below:

A site stability evaluation report, from a certified engineering geologist, is required for all new development or expansion of existing uses that assures site stability for a period of 75 years. Report shall include:

- Historical erosion rates;

- Topographical information (surveying report);

- Geological information;

- Erosion information (wave and tidal information);

- Landslide potential (possible effects of proposed development on landslide potential);

- Hydrologic information;

- Potential erodibility of site and proposed mitigation measures to minimize erosion during and after construction;

- Any other factors that may affect slope stability; and

- Other information required by relevant State agencies. 
Exceptions to the bluff setback requirements include

- Fences (wood: less than three feet in height; Wire: less than six feet in height);

- Landscaping, minor earthwork, steps; or

- Roof and wall projections (e.g., chimneys, bay windows, eves, etc.) may project into bluff setback up to 30 inches.

\section{Combining Designations}

Lands that are deemed hazardous, sensitive, culturally important, or found to contain natural resources, are given special land use labels termed "combining designations." These designations ensure a thorough review of the Site before development occurs.

There are three combining designations standards for development that apply to the Piedras Blancas Motel Site. These designations require additional regulations outlined in the ordinance and are listed below:

1. Sensitive Resource Area;

2. Flood Hazard Area;

3. Coastal Zone Boundary

\section{Coastal Plan Policy Document}

The Coastal Plan Policy Document is comprised of policy statements that supplement the North Coast Plan and Coastal Zone Land Use Ordinance. This document is intended to further implement the mandates of the California Coastal Act.

\section{Exemptions}

As a general guideline, any development that occurs on the Site is subject to the regulations of the Local Coastal Program (e.g., development plan approval, environmental review, etc.). However, the Department of Parks and Recreation does have the ability to issue its own building permits. Also, in instances of grading, if the area to be graded is less than one acre, then no permit is required. In cases greater than one acre, a permit must be obtained from the Regional Water Quality Control Board. Therefore, State Parks may process all building permits internally, as long as no development occurs, as defined by the Coastal Commission and California Coastal Act.

\section{Definition of Development}

According to the California Coastal Act, Development is defined as:

- Placement or erection of any solid material or structure;

- Discharge or disposal of any dredged material or of any gaseous, liquid, solid, or thermal waste; grading, removing, dredging, mining, or extraction of any materials; 
- Change in the density or intensity of use of land, including, but not limited to, subdivision pursuant to the Subdivision Map Act (commencing with Section 66410 of the Government Code), and any other division of land, including lot splits, except where the land division is brought about in connection with the purchase of such land by a public agency for public recreational use;

- Change in the intensity of use of water, or of access thereto; construction, reconstruction, demolition, or alteration of the size of any structure, including any facility of any private, public, or municipal utility; and

- Removal or harvesting of major vegetation other than for agricultural purposes, kelp harvesting, and timber operations which are in accordance with a timber harvesting plan submitted pursuant to the provisions of the Z'berg-Nejedly Forest Practice Act of 1973 (commencing with Section 4511).

As used in this section, "structure" includes, but is not limited to, any building, road, pipe, flume, conduit, siphon, aqueduct, telephone line, and electrical power transmission and distribution line (California Coastal Act, Section 30106, 2009).

\section{Common Overlapping Regulations}

A side effect of the regulatory complexity affecting the North Coast of San Luis Obispo County is that many of the planning documents and State regulations overlap. This section notes some of the more common overlapping regulations that may be encountered during development.

- Coastal Development Permit (California Coastal Commission)

$\checkmark \quad$ All development within the Coastal Zone shall obtain a coastal development permit issued by the California Coastal Commission or by San Luis Obispo County pursuant to Chapter 23.03 of the Coastal Land Use Ordinance.

- California Title 24 (State energy efficiency standards for buildings)

$\diamond \quad$ Enforced by State Building Standards Enforcement Unit

- California Title 25 (State regulation for RV Parks)

$\diamond \quad$ All development of RV parks or other non-permanent structures are subject to the regulations set forth by The California Department of Housing and Community Development, Title 25 (Chapters 2 and 2.2).

$\diamond \quad$ San Luis Obispo County acts as the enforcing body.

- Scenic Highway Corridor Protection Plan (San Luis Obispo County)

$\checkmark \quad$ Contains regulations already included in other County plans and land use ordinances. Created as part of the process to obtain State Scenic Highway status for Highway One from San Luis Obispo City to the Monterey County line. 


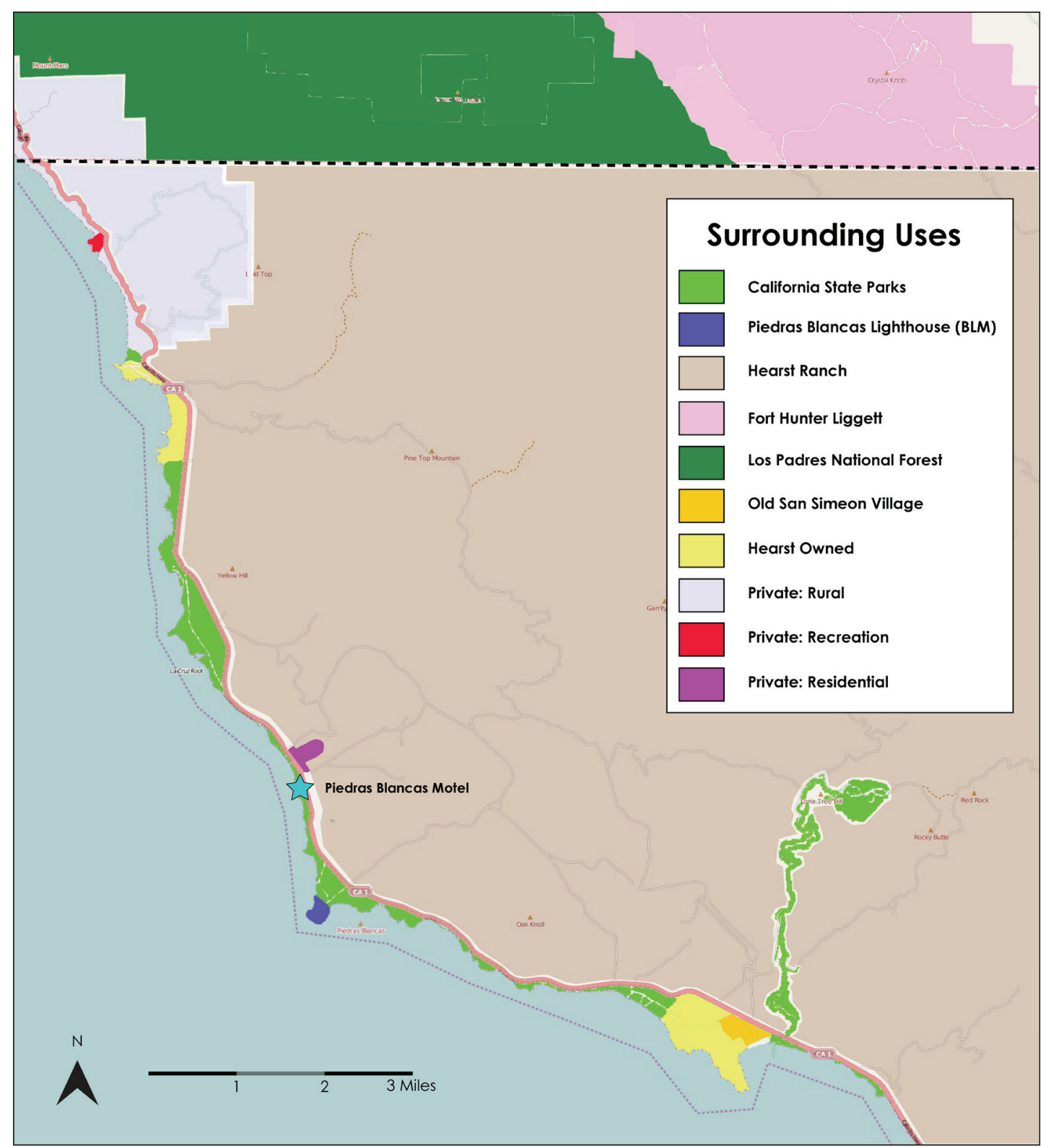

Figure 3.2 Surrounding Uses

\section{4: Surrounding Uses}

Land uses surrounding the Site are primarily related to agriculture and tourism. Uses within a ten-mile radius are listed below:

- Agriculture and Open Space

$\diamond \quad$ Hearst Ranch

$\diamond \quad$ Grazing land 
- Recreation and Tourism

$\diamond \quad$ Hearst San Simeon State Park

$\diamond \quad$ Elephant seal colony

$\diamond \quad$ Piedras Blancas Light Station (BLM)

$\diamond \quad$ Beaches and scenic coastline

$\diamond \quad$ California Coastal National Monument (BLM)

$\diamond \quad$ Transient lodging

$\diamond$ Restaurants

- Residential

$\diamond \quad$ Lighthouse View Estates

Recreational land uses are encouraged in the North Coast Plan and in the Coastal Plan Policies, especially those that are considered low-cost.

The Hearst Ranch Corporation has a major land holding adjacent to Piedras Blancas that currently consists of nearly 82,000 acres east / inland of Highway 1. According to the North County Plan, 98 percent of this land must remain in agricultural use. The remaining two percent is part of a proposed master plan development related to tourism. Homesite development is allowed on conservation easement land that is zoned for agriculture, however it is limited to the construction of only 27 homes (North Coast Plan, 2008).

\section{5: Stakeholders}

There are many groups that have diverse interests in the Site. These stakeholders range from government agencies to non-profits to private residents. Below is a list of stakeholders (both directly and indirectly involved) in the redevelopment of the Piedras Blancas Motel Parcel:

- California State Parks

- California Coastal Conservancy

- California Coastal Commission

- California Water Resources Control Board

- San Luis Obispo County

- San Luis Obispo Council of Governments

- San Luis Obispo County Office of Emergency Services 
Background Report

- California Department of Transportation

- Bureau of Land Management

- United States Forest Service

- Hearst Ranch Corporation

- Friends of the Lighthouse

- Lighthouse View Estates residents

- Cambria Chamber of Commerce

- San Simeon Chamber of Commerce

- Friends of Elephant Seal

- Monterey Bay National Marine Sanctuary

\section{6: Conclusion}

As with most coastal development in California, the regulatory climate surrounding the Site involves a complex array of governing documents, policies, permits, stakeholders and enforcement bodies. The site could accommodate a variety of allowed uses including a hotel, eatery, service station, and camping. In order to avoid development review and permitting from the County, State Parks must re-occupy the existing building and operate under the previously approved uses. Unless the landowner is willing to trigger the County regulatory process, they will only be able to rehabilitate the building through maintenance and repair to the interiors and aesthetic improvements to the exteriors.

For more in-depth information, please refer to planning document links listed below.

North Coast Area Plan: http://www.slocounty.ca.gov/Assets/PL/Area+Plans/North+Coast+Area+Plan.pdf

Coastal Zone Land Use Ordinance: http://www.slocounty.ca.gov/Assets/PL/Land+Use+Ordinances/Title+23++Coastal+Zone+Land+Use+Ordinance/Title+23+Coastal+Zone+Land+Use+Ordinance.pdf

Costal Plan Policy Document: http://www.slocounty.ca.gov/Assets/PL/Elements/Coastal+Plan+Policies.pdf California Coastal Act: http://www.coastal.ca.gov/coastact.pdf 


\section{Chapter 4: Market Analysis}

\section{1: Introduction}

The Site's market area is defined as the land between Andrew Molera State Park to the north and Hearst San Simeon State Park to the south, a driving distance of approximately 75 miles. From east to west, the market area extends from the ridge of the Santa Lucia Range to the Pacific Ocean. The market thus encompasses what is generally referred to as the "Big Sur Coast." A major tourist attraction, over 3 million visitors flock to this area annually to experience the undeveloped coastline and coast ridge that drops precipitously to the sea. Besides its heralded beauty, this stretch of coastline bespeaks a California of the past, which holds a spirit of discovery and a closer connection with natural forces that many visitors and residents feel akin to.

Unfortunately, many visitors are unable to afford overnight accommodations in the market area and instead travel out of the market area to seek lower priced accommodations. In fact, other than camping and RVs, there are no low-cost accommodations available on the Big Sur Coast. For the purpose of this analysis, "Iow cost" is defined as less than $\$ 60$ per night. This price point is intended to differentiate less-expensive hotels from hostel-type facilities. The Bridge Street Inn in Cambria is the only hostel between San Luis Obispo and Monterey.

This chapter provides an analysis of the 35 lodging facilities within the market area, categorizing them by lodging type and nightly rate. Information for each facility is also represented graphically (Figure 4.1 and Figure 4.2). The maps are intended to illustrate market composition by geographic location, and then by facility type and nightly rate. The maps can be used as a tool to identify market deficiencies. Market trends and other conditions are examined briefly at the end of the chapter.

*Note: This market study is based on rates obtained in October 2009. Nightly rates fluctuate and are subject to change.

\section{2: Market Area Lodging Facilities}

\section{Hotels}

For this study, the term "hotel" refers to any lodging facility with a primary structure containing guest rooms and other services such as dining and beverage provision. Lodging facilities that incorporate other overnight facilities are not considered hotels and are classified as tent camping, RV camping, cabins, and hostels.

There are 20 hotel facilities within the market area. Generally, hotels in the market area can be divided into the less expensive southern hotels of San Simeon, and the upscale, higher-cost hotels of northern Big Sur. Several of the Big Sur hotels, particularly in the north, are luxury resorts with nightly rates of over $\$ 200$. The most expensive hotel in the area is the Post Ranch Inn, with nightly rates ranging from $\$ 550$ to $\$ 2,185$ per night. The lowest hotel pricing available in the middle portion of the market area, near Lucia and Gorda, is approximately $\$ 150$ per night. 


\section{Tent Camping}

Within the market area, there are 12 facilities that provide tent camping. With 1,488 campsites, San Luis Obispo County holds more campsites than any other coastal county (California Coastal Commission, 2006). Twentyfive percent of all California coastal campsites are located within San Luis Obispo County. The typical nightly rate for campsites in the area ranges between $\$ 10$ and $\$ 30$. Sites that offer tent or RV camping in addition to motel or cabin facilities are categorized by the price of their motel or cabin room rates, not by the price to rent a campsite.

\section{RV Camping}

Within the study market area, there are three facilities that provide RV accommodations. All are located in the northern section of the market. RV sites nearest to Piedras Blancas are 35 miles to the south in Morro Bay, for approximately $\$ 40$ per night. Three locations in Big Sur offer RV accommodations at a nightly rate of approximately $\$ 45$. RV camping is not currently allowed under the North Coast Plan at the Piedras Blancas Motel site. However, it was a historical use at the Site and was allowed by the County as a non-conforming use, grandfathered after the regulations went into effect.

\section{Cabin/Yurt}

Within the study market area, there are five facilities that provide cabin or yurt lodging. The terms "cabin" or "yurt" do not necessarily mean low-cost. Nightly rates at the cabin/yurt facilities range from \$88 to \$290.

\section{Hostel}

There is only one hostel within the market area, the Bridge Street Inn, in Cambria. The nightly rate for a bed in a shared room begins at $\$ 25$. Private rooms can be rented for $\$ 65$ per night.

\section{3: Trends}

\section{Demand Growth}

California's population is projected to grow at an annual rate of 1.2 percent over the next 15 years (PPIC, 2005). At this pace, there will be 46.7 million people living in California by the year 2025. This translates to approximately 500,000 new residents per year. This statistic suggests the potential for a growing "local" market for overnight accommodation. According to the California Department of Finance, San Luis Obispo County grew by almost 10 percent from the years 2000 to 2009. Compared to the eight percent growth experienced in Santa Barbara County and 7.5 percent in Monterey County during the same time period, San Luis Obispo is the fastest growing county in the Central Coast.

\section{Low-Cost Coastal Accommodations}

Among California's 16 coastal counties, the number of hotels and lodging facilities has increased 32 percent since 1990. As of 2004, there were 1,678 lodging facilities in California's coastal counties. Of these facilities only 134 (7.9 percent) are considered low-cost, or under $\$ 100$ per night. These generally include campsites, hostels, 
Market Area: Approximately 75 miles of coastline between Cambria and Andrew Molera SP

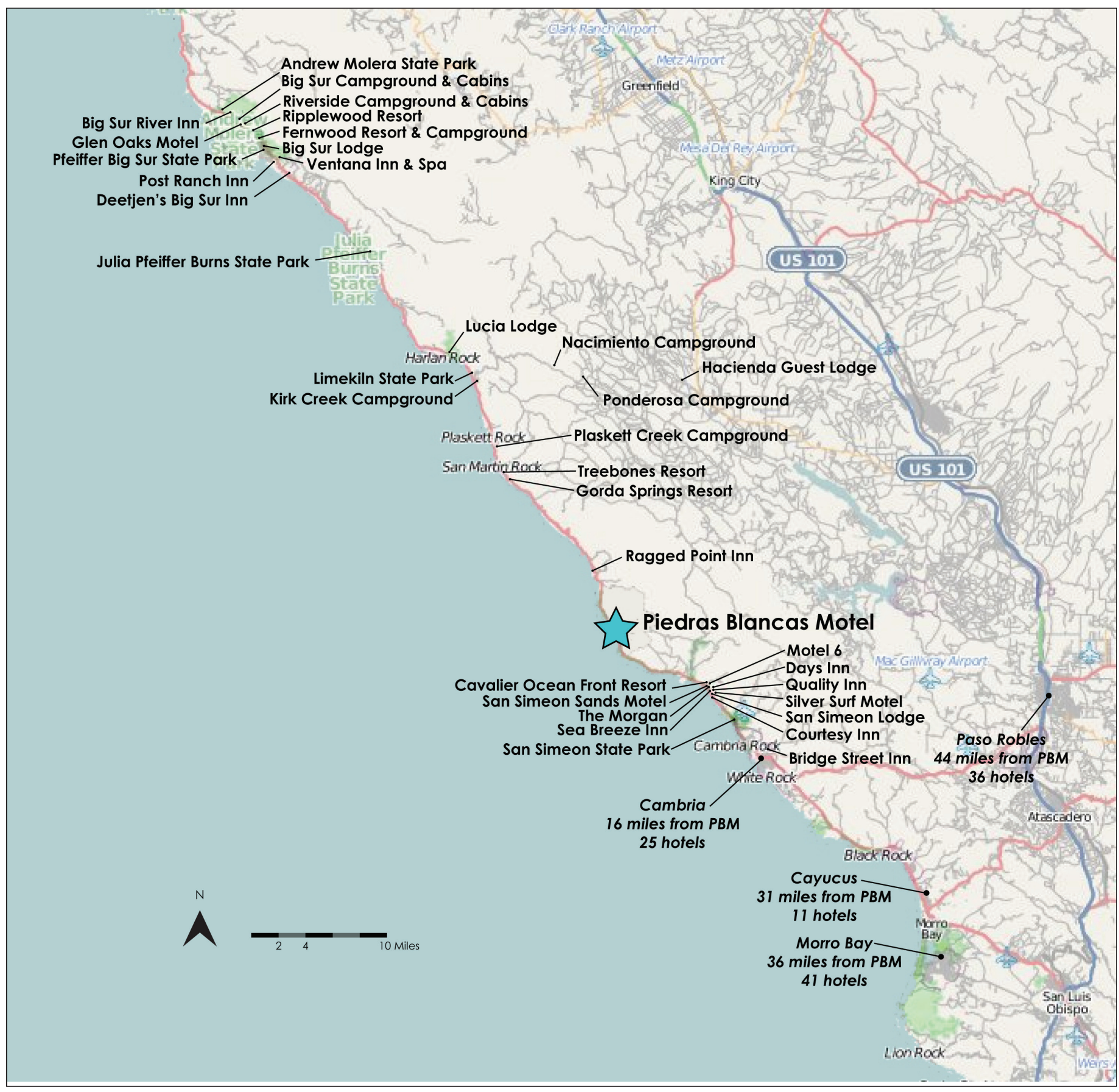

Figure 4.1 Geographic Map of Market Area

The map shown in Figure 4.1 provides a geographic representation of all lodging facilities in the study area on a topographical map of the central coast of California. Facility names are provided next to the geographic location. 


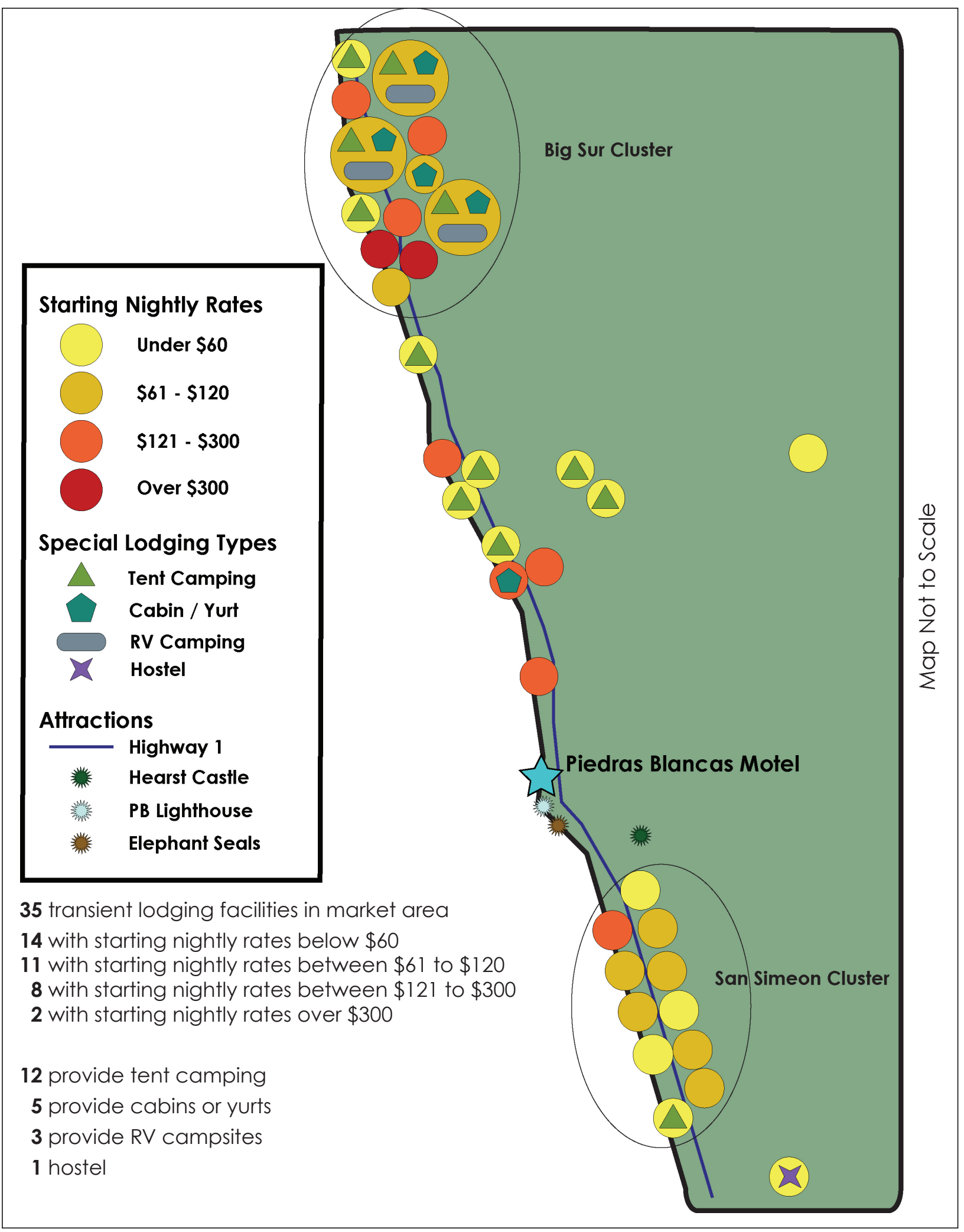

Figure 4.2 Abstract Map of Market Area

The map shown in Figure 4.2 is an abstract representation of the market area, and provides information on facility type using symbols, and starting nightly rates. 
RV parks, and low cost hotels (California Coastal Commission, 2006).

\section{4: Example of Low-Cost Coastal Lodging}

This example is included to provide insight from previous initiatives for low-cost coastal lodging, and can be considered by stakeholders when choosing a development alternative.

\section{Pigeon Point Lighthouse Hostel}

During the fuel crisis of the mid-1970s, there was a substantial increase in the number of visitors to California hostels. In 1972, there were 5,375 overnight stays at California hostels. By 1976, the number of annual overnight stays was nearly 18,000; a 333 percent increase (Dulin, 2003). Because of this increased interest in hostel accommodations, combined with the formation of the California Coastal Commission (1972), and passage of the California Coastal Act and Coastal Conservancy Act (1976) (which put a high priority on the development of low cost overnight accommodations) the State began to actively pursue development of hostels to provide low cost coastal access and lodging.

This effort culminated in the passage of State Assembly Bill 400 in 1976, which directed the Department of Parks and Recreation to submit a plan for coastal hostel construction. The California State Park System Coast Hostels Facilities Plan, submitted in 1978, stated that it was the long-range goal of State Parks to, "... provide facilities in conjunction with all major recreation corridors throughout the state (O'Brien, 1998)." State planners identified 37 potential hostel sites along the coast, from which nine were chosen for development in a pilot study. In the 1978 budget for State Parks, $\$ 1.9$ million was set aside for the construction of coastal hostels. Two years later the hostel at Pigeon Point Lighthouse was opened to the public (O'Brien, 1998).

In May 2005, the California Department of Parks and Recreation purchased the Pigeon Point Lighthouse property from the United States Coast Guard. The hostel is currently being operated by the Golden Gate Council of Hostelling International USA.

Pigeon Point Lighthouse Hostel offers four three-bedroom lodging houses. Nightly rates for shared rooms are $\$ 12$ for children under 12 and $\$ 25$ for adults. Private room rates range from $\$ 59$ to $\$ 111$ per night, depending on the number of beds per room. The maximum nightly capacity at the Pigeon Point Hostel is 50 people. In 2009 , the hostel had 12,500 overnight occupancies, or an average of 35 bed occupancies per night. The 2009 number is only slightly less than the maximum overnight occupancies of 13,000.

\section{5: Conclusion}

The market analysis indicates that there is a lack of diverse, low-cost lodging facilities along the coastline between Big Sur and Cambria. With high numbers of annual visitors and an increasing coastal population, the need for low cost lodging facilities will continue to increase. Many visitors to the area seeking an alternative to camping will find it difficult to afford the luxury resorts and hotels currently scattered along the Big Sur Coast. Due to its unique geographic location and proximity to natural resources, the Piedras Blancas Site is ideally 
Background Report

positioned to serve these lodging needs. 


\section{Chapter 5: Preferred Development Alternative}

\section{1: Introduction}

The preferred development alternative incorporates existing regulations into a plan capable of meeting salient market deficiencies. Caron Design created three architectural illustrations representing three distinct levels of development at the Site. These illustrations were presented to the County of San Luis Obispo Planning Department at a pre-application meeting held on April 26. The Consultant team used feedback from the County to narrow the options and finalize the illustration of the preferred alternative.

In addition to the two main buildings, the preferred alternative also incorporates tent cabins, additional parking, and an educational facility. The educational facility could be similar to a National Park visitor center, with informational displays, guidebooks, video booths, and park rangers. It could highlight the history, native plants and wildlife, and the geology of he area.

The Site could also serve as a stop for travellers along the California Coastal Trail. In the site plan of the preferred alternative, the current alignment of Highway 1 is indicated to become a link in the Trail.

Although the architectural site plan of the preferred alternative was completed as part of this study, it is not included here because it was considered proprietary information at the time of submission. 
Background Report

This Page Intentionally Left Blank 


\section{Chapter 6: Potential Site Improvements}

\section{1: Introduction}

Due to the physical and regulatory constraints at the Piedras Blancas Site, the potential future Site improvements have been organized into three levels of improvement options. The option levels are listed in order of least expansive to most expansive. It is assumed that the least expansive option will prompt minimal regulatory oversight, and the most expansive option may prompt more regulatory oversight. Therefore, the improvement levels also progress in order of difficulty of implementation.

\section{2: Improvement Options}

Level one improvements:

The following improvement are considered baseline and necessary for operational feasibility of the Motel.

- Repair cracks in concrete floor

- Repair walls

- Replace and reinforce chimney

- Landscaping

- Aesthetic improvements

- Re-orient rooms towards ocean

- Remodel room interiors

- Remodel café interior

- Signage

- Upgrade plumbing and fixtures

- Upgrade electrical system

- New flooring

- Upgrade HVAC

- New paint 


\section{Level two improvements:}

The following improvements are considered to have a moderate level of development.

- Individual unit patios

- $\quad$ Fire pit

- Tents campsites on bluff

- Trails and foot-bridges

- Informational kiosks

\section{Level three improvements:}

The following improvements are considered to have the most expansive impacts.

- Education center

- Event area or facility

- Tent-cabins or casitas

- Expanded parking area

- Bus or RV staging area

- Second entrance

- Coastal erosion mitigation or buffer 


\section{Chapter 7: Financial Analysis}

\section{1: Introduction}

A financial analysis was conducted to determine the financial feasibility of renovating the Structure and operating it as a hostel. The analysis involved an inventory of operating expenses and construction costs. Using the cost estimates, a basic pro forma spreadsheet was used to calculate the financial performance over a six year time period (operating as a hostel).

\section{2: Hostel Information}

\begin{tabular}{|l|l|l|l|l|l|}
\hline \multirow{5}{*}{} & Room Type & Rate per person & \# of rooms & \# of beds per room & Beds per room type \\
\cline { 2 - 6 } & Dormitory & $\$ 40$ & 5 & 6 & 30 \\
\cline { 2 - 6 } & Family & $\$ 20$ & 4 & 4 & 16 \\
\cline { 2 - 6 } & Couples & $\$ 50$ & 2 & 2 & 4 \\
\hline Totals & & & 11 & & 50 \\
\hline Average & & $\$ 34.40$ & & & \\
\hline
\end{tabular}

\section{3: Operating Expenses}

The operating expenses listed in the table below are estimates based on similar facilities and industry standards.

\begin{tabular}{|l|l|}
\hline Banking & $\$ 6,500$ \\
\hline Building Repairs & $\$ 8,000$ \\
\hline Landscaping & $\$ 5,000$ \\
\hline Advertising / Marketing & $\$ 5,000$ \\
\hline Internet Service & $\$ 1,500$ \\
\hline Management (on-site) & $\$ 75,000$ \\
\hline Maintenance / Labor & $\$ 70,000$ \\
\hline Payroll Service & $\$ 500$ \\
\hline Payroll Taxes & $\$ 10,000$ \\
\hline Supplies & $\$ 5,000$ \\
\hline Insurance & $\$ 10,000$ \\
\hline Electricity & $\$ 25,000$ \\
\hline Water & $\$ 5,000$ \\
\hline Propane & $\$ 2,000$ \\
\hline Trash & $\$ 5,500$ \\
\hline Office Supplies & $\$ 7,000$ \\
\hline Telephone & $\$ 2,500$ \\
\hline Contingency & $\$ 35,000$ \\
\hline Total & $\$ 278,500$ \\
\hline
\end{tabular}




\section{4: Construction Costs}

The following tables provide a low and high range of construction cost estimates to perform the initial improvements to the Structures. These cost estimates are based on industry standards and interviews with area real estate developers (M. Frank of Watt Communities, May 2010). Due to the somewhat remote location of the Site, construction costs will be inflated based on the travel time of the contractor and proximity of material sources.

\section{Piedras Blancas Motel: Construction Cost Estimates (LOW)}

\begin{tabular}{|lcrl|}
\hline & Sq. Ft. & Cost $/$ Sq. Ft. & Total \\
\hline Hostel & 5,200 & $\$ 150$ & $\$ 780,000$ \\
Café & 3,000 & $\$ 200$ & $\$ 600,000$ \\
& & & \\
\hline Subtotal & 8,200 & & \\
\hline Grand Total & & & $\$ \mathbf{1 , 3 8 0 , 0 0 0}$ \\
\hline
\end{tabular}

Plumbing upgrades

Chimney replacement

Concrete floor

Electrical

Flooring

HVAC

Drywall

Re-orientation

Windows

Landscaping

Paint

Misc.

Total

$\begin{array}{rr}5 \% & \$ 69,000 \\ 5 \% & \$ 69,000 \\ 22 \% & \$ 303,600 \\ 5 \% & \$ 69,000 \\ 5 \% & \$ 69,000 \\ 5 \% & \$ 69,000 \\ 15 \% & \$ 207,000 \\ 10 \% & \$ 138,000 \\ 12 \% & \$ 165,600 \\ 6 \% & \$ 82,800 \\ 5 \% & \$ 69,000 \\ 5 \% & \$ 69,000 \\ 100 \% & \$ 1,380,000\end{array}$




\section{Piedras Blancas Motel: Construction Cost Estimates (HIGH)}

\begin{tabular}{|lrrr|}
\hline & Sq. Ft. & Cost $/$ Sq. Ft. & \multicolumn{1}{c|}{ Total } \\
\hline Hostel & 5,200 & $\$ 200$ & $\$ 1,040,000$ \\
Café & 3,000 & $\$ 250$ & $\$ 750,000$ \\
& & & \\
\hline Subtotal & 8,200 & & $\$ \mathbf{1 , 7 9 0 , 0 0 0}$ \\
\hline Grand Total & & &
\end{tabular}

$\begin{array}{lrr}\text { Plumbing upgrades } & 5 \% & \$ 89,500 \\ \text { Chimney replacement } & 5 \% & \$ 89,500 \\ \text { Concrete floor } & 22 \% & \$ 393,800 \\ \text { Electrical } & 5 \% & \$ 89,500 \\ \text { Flooring } & 5 \% & \$ 89,500 \\ \text { HVAC } & 5 \% & \$ 89,500 \\ \text { Drywall } & 15 \% & \$ 268,500 \\ \text { Re-orientation } & 10 \% & \$ 179,000 \\ \text { Windows } & 12 \% & \$ 214,800 \\ \text { Landscaping } & 6 \% & \$ 107,400 \\ \text { Paint } & 5 \% & \$ 89,500 \\ \text { Misc. } & 5 \% & \$ 89,500 \\ & & \\ \text { Total } & 100 \% & \$ 1,790,000\end{array}$




\section{5: Financial Pro Forma}

Although financial pro formas were conducted for both high and low cost estimates as part of the project, they are not included here because they were considered proprietary information at the time of submission. 


\section{Chapter 8: Potential Funding Sources}

\section{1: Introduction}

This chapter provides an assessment of potential sources to fund implementation of the preferred development alternative for the Site. Both public and private funding sources are described. The collaborative nature, and the focus of serving lower cost overnight lodging needs on the coast, make the Piedras Blancas Project attractive, particularly for a public-private funding venture. It is possible that more than one funding source may be required for this Project. Additional funding will be required for operational costs, subsequent to redevelopment.

\section{2: Exactions and Impact Fees}

An exaction is a tool that the County can use to collect impact fees from developers in order to fund infrastructure improvements or other related projects. For example, as discussed in Section 3.3, the North Coast Plan stipulates that the Hearst Corporation pay impact fees for the development of the staging area near the Hearst Castle. These impact fees are to support either a 100-bed hostel or a 50-site campsite.

\section{3: Public/Private Partnership}

California Department of Parks and Recreation may choose to distribute a request for qualifications to private developers that have an expertise in developing, redeveloping, and/or managing low cost, overnight lodging facilities, and have experience with similar projects. After the completion of development, the facility may be controlled and operated by the developer or contracted to a third party operator (e.g., Bridge Street Inn, American Youth Hostel Association).

\section{4: State Grants for Nature Education Centers}

The Nature Education Facilities Program was created with the overall goal of increasing the public's understanding of California's natural resources and inspiring environmental stewardship. The funds will be given to projects that enhance development of nature education facilities and galleries that inspire and educate the public, as well as, research equipment and facilities for marine wildlife conservation research. Grant funded projects must be open to the public or support facilities that are open to the public. The program accepts applications from cities, counties, California state agencies, districts, and 501(c)(3) nonprofit organizations. The California State Parks department oversees the Nature Education Facilities. 


\section{4: California Coastal Conservancy, California Coastal Trail}

Currently nearly half of the proposed 1,200 mile California Coastal Trail is completed. The Coastal Conservancy is committed to promoting and facilitating the formation of the trail. In 2001 Senate Bill 908 required the California Coastal Conservancy to provide grants and assistance to organizations or agencies involved in the formation and expansion of inland trails that may be linked to the Coastal Trail. http://www.scc.ca.gov/index. php? cat $=20$

\section{5: Recreational Trails Project Funding}

http://www.americantrails.org/resources/fedfund/index.html

\section{6: Fee Waivers}

Fee exemptions may be used as tools to help reduce costs of the project, and in essence provide "funding" for implementation.

The San Luis Obispo County Director of Public Works may grant a fee waiver, up to $\$ 3,000$, for land use and construction permits on development projects that are proposed by nonprofit organizations for the benefit of the community.

The County Board of Supervisors may authorize additional fee waivers for projects with inherent public benefit. The total waiver amount may not exceed $\$ 5,000$.

\section{7: Conclusion}

The funding options addressed in this chapter are intended to give project managers guidance on funding options. Of any of the subjects addressed in this document, the Potential Funding Sources chapter is the best candidate for a working document, one that should be referred to, and updated constantly. This discussion will hopefully give rise to new opportunities, and offer direction on how to take full advantage of more traditional ones. 


\section{Chapter 9: Recommendations}

\section{1: Recommendations}

Perform first level of improvements immediately, as funding allows

The first level of improvements, listed in Chapter Six, may be performed without drafting a development plan. These improvements are necessary to ensure the viability and structural integrity of the Structure.

\section{Operate as a hostel}

After the initial improvements are performed, it will be possible to operate the Structure as a hostel to provide low-cost lodging. This lodging model is consistent with the objective of State Parks and the Costal Conservancy to provide a low-cost lodging alternative to tent or RV camping.

\section{Set up a management structure involving a third party private operator or concessionaire}

The Consultant team recommends that the hostel be operated by a private entity with experience in successful hostel management, such as Hosteling International. A concessionaire should also operate the café facility.

\section{Draft proposal for second phase of development}

As the initial improvements get under way, State Parks should draft a development plan for the second phase of the Site development. This second phase may include the level two and three improvements listed in Chapter Six.

\section{Begin gathering CEQA information}

The second phase of development will require a review of potential environmental impacts. Under the California Environmental Quality Act (CEQA), an initial study must be performed to determine if the potential impacts would necessitate an Environmental Impact Report (EIR). State Parks may be able to use portions of the Caltrans EIR for the realignment of Highway 1 at Piedras Blancas.

\section{Public Outreach}

Throughout the redevelopment process, State Parks should engage local residents and stakeholders to keep them informed, gather feedback, and ensure community approval.

\section{Incorporate renewable or "green" energy sources}

In order to mitigate negative environmental impacts that may result from powering the facility, the State should investigate the possibility of installing on-site renewable or "green" energy sources such as photo voltaics or wind generators. In the long-term, a renewable energy strategy will greatly reduce operating costs. 
Background Report

This Page Intentionally Left Blank 


\section{References}

Big Sur Arts. (2009) Retrieved from http://bigsurarts.wikispaces.com.

County of San Luis Obispo. (2008). North Coast Area Plan. San Luis Obispo, CA.

County of San Luis Obispo. (2007). Coastal Plan Policies. San Luis Obispo, CA.

County of San Luis Obispo. (2009). Coastal Zone Land Use Ordinance. San Luis Obispo, CA.

Dulin, E. (2003). Preservation for the People: Seventy Years of American Youth Hostels (Master's Thesis, University of Pennsylvania, 2003).

Hamilton, G. (1974). Where the Highway Ends. San Luis Obispo: Padre Productions.

Hayden, D. (1995). The Power of Place. Cambridge: MIT Press.

Miller, H. (1957). Big Sur and the Oranges of Hieronymus Bosch. New York: New Directions Publishing Corporation.

Monterey County Convention and Visitors Bureau. (2009). Retrieved from http://www.seemonterey.com/bigsur-california/bigsurarts.

O'Brien, B. (1998). Oceanside Hostels, and More to Come. Coast and Ocean Magazine.

RRM, Inc. (2006). Phase I Environmental Site Assessment: Piedras Blancas Motel and RV Park. Santa Cruz, CA.

State of California. (2009). California Coastal Act. Sacramento, CA

State of California Coastal Commission. (2006). Condominium-Hotel Development in the Coastal Zone. San Francisco, CA

State of California Department of Transportation. (2008). Piedras Blancas Realignment: Draft Environmental Impact Report/Environmental Assessment.

State of California Department of Transportation. (2008). Piedras Blancas Realignment: Draft Project Study Report.

State of California Department of Transportation. (1996). Historic Resource Evaluation Report on the Rock Retaining Walls, Parapets, Culvert Headwalls, and Drinking Fountains along the Carmel to San Simeon Highway.

Taylor and Syfan Consulting Engineers, Inc. (2008). Structural Evaluation and Rehabilitation Report: Peidras Blancas Motel and RV Park. San Luis Obispo, CA: Bret Rooks and Stephen Taylor. 
